\title{
Assessment of Strike of Adult Killer Whales by an OpenHydro Tidal Turbine Blade
}

$\begin{array}{ll}\text { TJ Carlson } & \text { BE Watson } \\ \text { JL Elster } & \text { AE Copping } \\ \text { ME Jones } & \text { M Watkins }\end{array}$

Pacific Northwest National Laboratory

R Jepsen

K Metzinger

Sandia National Laboratories

February 2012

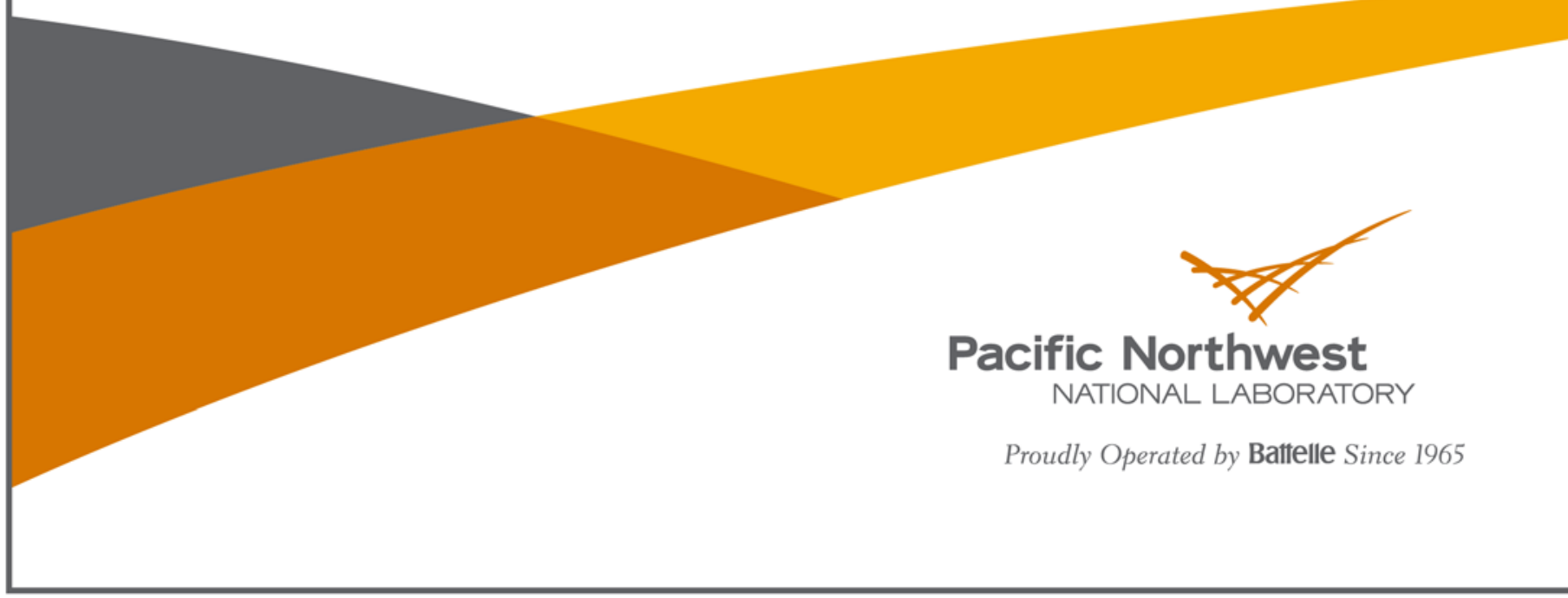




\title{
DISCLAIMER
}

This report was prepared as an account of work sponsored by an agency of the United States Government. Neither the United States Government nor any agency thereof, nor Battelle Memorial Institute, nor any of their employees, makes any warranty, express or implied, or assumes any legal liability or responsibility for the accuracy, completeness, or usefulness of any information, apparatus, product, or process disclosed, or represents that its use would not infringe privately owned rights. Reference herein to any specific commercial product, process, or service by trade name, trademark, manufacturer, or otherwise does not necessarily constitute or imply its endorsement, recommendation, or favoring by the United States Government or any agency thereof, or Battelle Memorial Institute. The views and opinions of authors expressed herein do not necessarily state or reflect those of the United States Government or any agency thereof.

\author{
PACIFIC NORTHWEST NATIONAL LABORATORY \\ operated by \\ BATTELLE \\ for the \\ UNITED STATES DEPARTMENT OF ENERGY \\ under Contract DE-AC05-76RL01830 \\ Printed in the United States of America \\ Available to DOE and DOE contractors from the \\ Office of Scientific and Technical Information, \\ P.O. Box 62, Oak Ridge, TN 37831-0062; \\ ph: (865) 576-8401 \\ fax: $(865) 576-5728$
ail: reports@adonis.osti.gov \\ Available to the public from the National Technical Information Service, \\ U.S. Department of Commerce, 5285 Port Royal Rd., Springfield, VA 22161 \\ ph: (800) 553-6847 \\ fax: (703) 605-6900 \\ email: orders@ntis.fedworld.gov \\ online ordering: http://www.ntis.gov/ordering.htm
}

ay

This document was printed on recycled paper.

(9/2003) 


\title{
Assessment of Strike of Adult Killer Whales by an OpenHydro Tidal Turbine Blade
}

\author{
TJ Carlson \\ BE Watson \\ JL Elster \\ AE Copping \\ ME Jones \\ M Watkins \\ Pacific Northwest National Laboratory \\ R Jepsen \\ $\mathrm{K}$ Metzinger \\ Sandia National Laboratories
}

February 2012

Prepared for

the U.S. Department of Energy

under Contract DE-AC05-76RL01830

Pacific Northwest National Laboratory

Richland, Washington 99352 



\section{Summary}

Snohomish Public Utility District \#1 (SnoPUD) proposes to deploy two OpenHydro tidal turbines in Admiralty Inlet, Puget Sound. The fisheries service of the National Oceanic and Atmospheric Administration (NOAA Fisheries) has expressed concerns that the turbines may cause a risk for the highly endangered Southern Resident Killer Whale (SRKW) population if a whale is struck by an operating turbine. NOAA Fisheries is responsible for protecting the (fewer than 90) SRKWs under the Endangered Species Act and the Marine Mammal Protection Act. Because the SRKW numbers are so small, significant injury of a single animal could place the population in jeopardy.

The potential risk to a SRKW can be parsed into the probability that a whale would encounter a turbine, the probability that the encounter would injure the whale, and the severity of any injury. During a meeting with representatives of SnoPUD, OpenHydro, the Department of Energy, and NOAA Fisheries, participants agreed that the probability of a SRKW encountering a turbine by chance is negligibly small as the whales spent greater than 97 percent of their time in Admiralty Inlet in the top 30 meters of water, while the turbines are located at 55 meters of depth, and the SRKW have highly evolved acoustic sensory capabilities that would help them detect the presence of a turbine. NOAA Fisheries expressed concerns over the potential severity of a strike on a SRKW should it occur. A proposed solution was to conduct an estimate of the level of injury that might occur from an encounter between a turbine blade and a SRKW, which would allow NOAA Fisheries to determine the permitting requirements for the tidal project.

Pacific Northwest National Laboratory (PNNL) and Sandia National Laboratories (SNL) were tasked by the Department of Energy to carry out an analysis of the mechanics and biological consequences of strike of a SRKW by an OpenHydro turbine blade. The approach taken by the two laboratories was to: 1) develop a scenario for the most severe strike of a SRKW; 2) determine the morphological and biomechanical properties of SRKW tissues that might be affected by a strike; 3) model the forces of a strike; and 4) estimate the potential effects on SRKW tissue and bone of a strike.

PNNL and SNL developed a worst case exposure scenario for strike of a SRKW. SNL modeled a turbine blade (based on proprietary design data obtained from OpenHydro), and calculated the force of blade impact on the head of an adult male SRKW, weighing approximately 4000 kilograms. The adult SRKW was selected for the model because an adult has a large body mass where more of the energy in a blade strike will be absorbed by the whale's tissue rather than going into momentum transfer that would push the whale out of the path of the turbine blade. This scenario would maximize the risk of injury to the SRKW. Although a juvenile SRKW might intuitively be considered to be at greater risk of injury, because of much smaller mass $(\sim 500 \mathrm{~kg})$ more of the energy in the blade strike would go into momentum transfer pushing the juvenile SRKW out of the path of the turbine's blades leaving much less available to damage tissue.

SNL built models of the turbine blades and their motion using specifications and data supplied by OpenHydro (Figure ES-1), and of an adult male SRKW using data available in the literature (Figure ES2). 

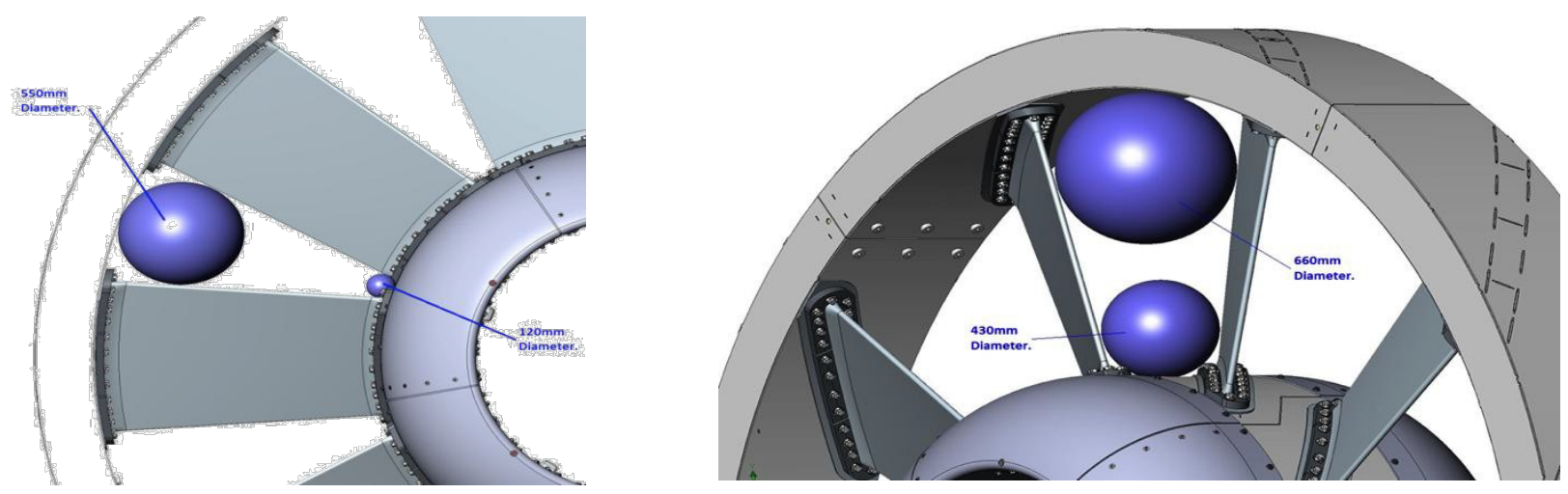

Figure ES-1. Drawings of the OpenHydro turbine blade assembly, as specified by OpenHydro, showing spacing of blade edges (left) and the spacing between blades (right). Also shown is the length of the blades (approximately $1.25 \mathrm{~m}$ ) after accounting for the open hub of the blade assembly that has a diameter of $4.8 \mathrm{~m}$.

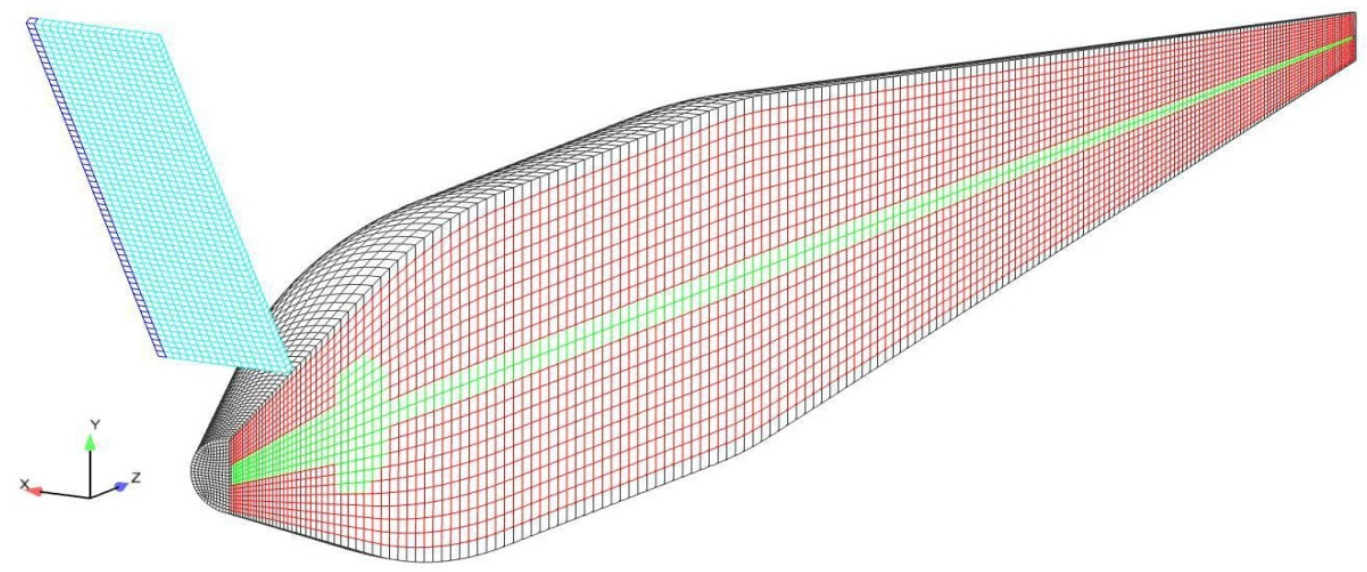

Figure ES2. The finite element mesh created for the model of the SRKW and the tidal turbine blade. The turbine is represented by a single blade. Due to the ducted turbine design, which encloses the tips of the turbine blades, and the spacing between blades, strike could only conceivably occur on the rostrum of a SRKW.

Recent NOAA publications provided appropriate SRKW swimming speeds of $1 \mathrm{~m} / \mathrm{sec}$ to $3 \mathrm{~m} / \mathrm{sec}$ for the type of encounter envisioned in this scenario. The modeling results showed maximum stresses (pressure) for turbine blade strike of the head of an adult male SRKW to range between 2350 to $2365 \mathrm{kPa}$, with strains (tissue elongation) of 73-93 percent for the most probable rotation speed of the turbine.

PNNL obtained data for the morphology and anatomy from CT scans of the head of an adult SRKW that died in 2002 (Figure ES-3). Information on the biomechanical properties of whale tissues was found in the scientific literature. 

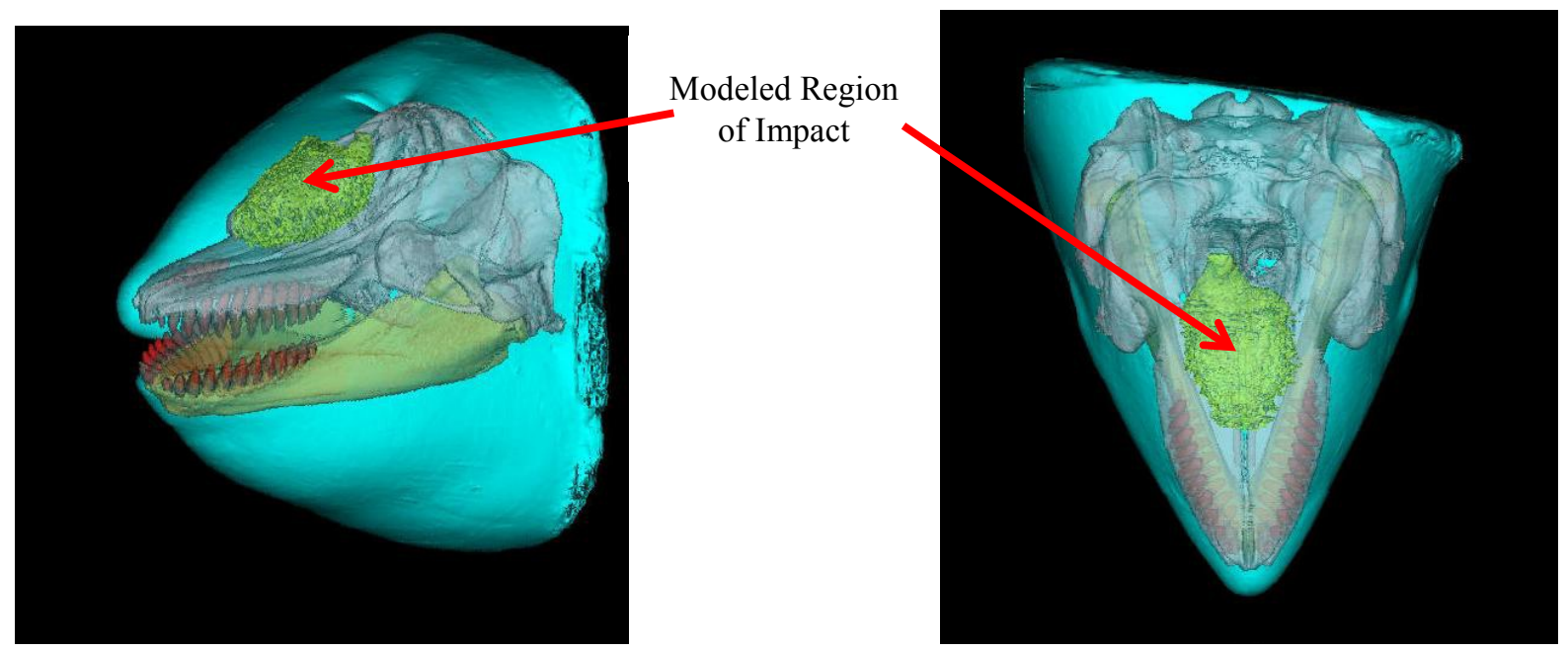

Figure ES-3. CT scan based images of the head of an adult female SRKW from the side (left), and from top view (right). The teeth are shown in red, bone in light color, and the various soft tissues in other colors. The region of impact used for modeling purposes is indicated.

The adult killer whale for which CT scan data were available and the adult killer whale modeled were similar enough in size so that the available morphology and anatomy data from CT scans could be used in assessment of the probable injury to an adult killer whale caused by turbine blade strike. The tissues of concern included the skin of the whale, other soft tissue, and mandibular bone. Very little is known about the biomechanical properties of whale tissue, particularly the skin, which functions to resist mechanical and other damage and to spread the force of an impact across a region that minimizes the forces acting on underlying tissues. For the purposes of this analysis, several natural and synthetic rubber material properties were considered as surrogates for SRKW skin.

Comparison of the maximum force acting on soft tissue and bone, estimated by SNL using the finite element models of the turbine blade and whale, with the tissue biomechanics data developed by PNNL provided the basis for assessment of probable injury to SRKW. The analysis found that the maximum levels of stress acting on whale tissue and bone corresponded to tissue response (strain) in the elastic range where whale tissue would be expected to return to their normal shape when the force of the turbine blade was removed without causing permanent change to the tissue. In addition the stresses and strains estimated using the blade and whale models were well below the yield strength for similar material including natural and synthetic rubber and human skin, by a factor of 3 or more.

The results of these analyses provide the following insights into the potential risk of encounter to a SRKW with an OpenHydro tidal turbine in Admiralty Inlet:

- PNNL/SNL analyses determined that a SRKW is not likely to experience significant tissue injury from impact by an OpenHydro turbine blade.

- If whale skin behaves similarly to the materials considered as surrogates for the upper dermal layers of whale skin, it is expected that in the case of a strike, whale skin tissue and the underlying soft tissue would deform, absorb the force of the strike, and return to normal condition after the pressure was removed. These data indicate that the skin would not be torn by blade strike. Using limited data on the strike pressure needed to fracture the mandibular bone (jawbone) of a North Atlantic Right Whale, and assuming the SRKW mandibles have similar biomechanical properties to those of Right 
Whales, the highest stress predicted by the model (about $3750 \mathrm{kPa}$ ) is highly unlikely to result in the fracture of a SRKW mandible.

There are a number of areas where the PNNL/SNL analysis could not provide insight:

- PNNL/SNL analyses could not provide insight into the potential for subtler changes to SRKWs from an encounter with the turbine, such as changes in behavior; and

- PNNL/SNL analyses do not adequately inform turbine interactions for other whales with other turbines.

The PNNL/SNL analyses were limited by the available time frame in which results were needed and focused on the mechanical response of whale tissues and bone to blade strike. Additional information on the biomechanical properties of marine mammal tissues and finite model refinements could help to further fine-tune this analysis. This analysis concentrated on the open center design specific to the OpenHydro turbine; the results may not be directly comparable to other turbine designs. 


\section{Acknowledgments}

This report has undergone limited review. As an additional round of review is completed, the report will be revised and be reissued.

This study was conceived through the joint efforts of the Department of Energy (DOE), the National Oceanic and Atmospheric Administration (NOAA), Snohomish PUD, OpenHydro, the University of Washington - Northwest National Marine Renewable Energy Center (UW-NNMREC), Pacific Northwest National Laboratory (PNNL) and Sandia National Laboratories (SNL). Understanding the potential severity of strike from an OpenHydro turbine blade on a Southern Resident Killer Whale (SRKW) in Admiralty Inlet, Puget Sound, is a necessary step in the responsible deployment of tidal turbines in these waters.

Rich Jepsen and Kurt at Metzinger at SNL undertook the engineering analysis, based on turbine specifications supplied by OpenHydro, and tidal velocities supplied by UW- NNMREC. Sandia analyses were passed on to the biomechanical analysis team at PNNL.

Tom Carlson, Mike Watkins and their team at PNNL examined the physiological and biomechanical properties of SRKWs and analyzed the likely effect of impacts, drawing from the engineering analysis.

Dr. Ted Cranfield at the University of California Santa Cruz kindly supplied the team with CT scans of the head of a SRKW. 



\section{Contents}

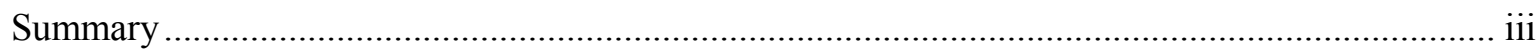

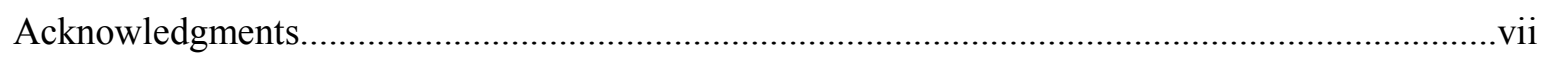

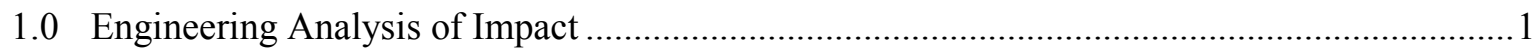

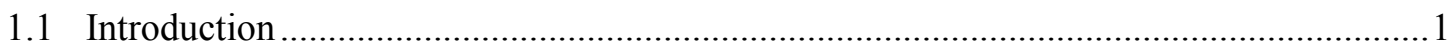

1.2 Geometry and Operational Characteristics of OpenHydro Turbine .................................

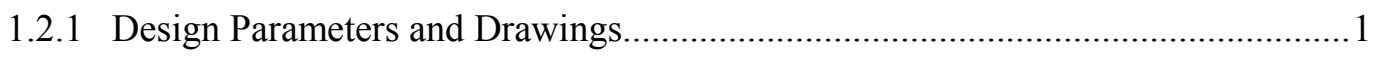

1.2.2 Turbine and Blade Material Properties ...............................................................2

1.2.3 Rotor Rotation Rates and Blade Speed ...........................................................

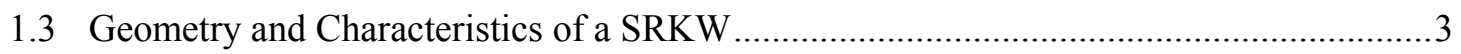

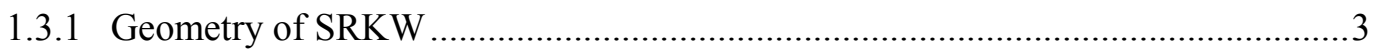

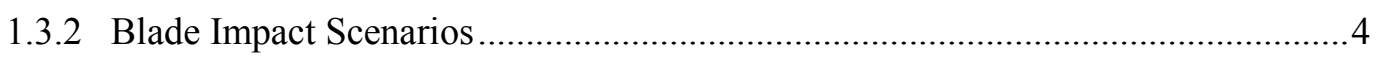

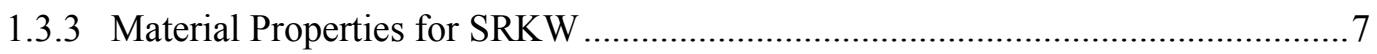

1.4 Analysis with Finite Element Model..........................................................................

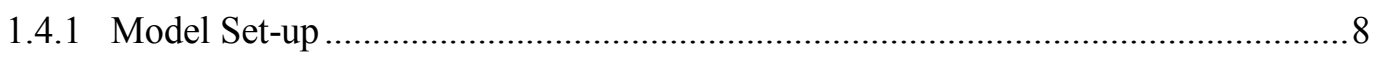

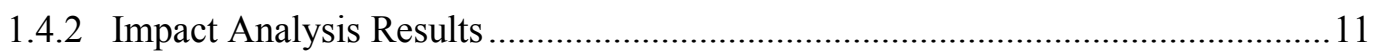

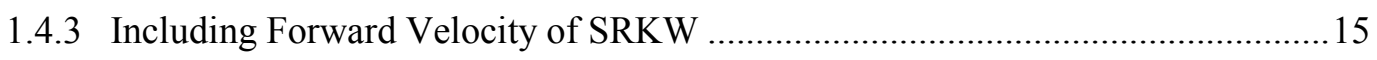

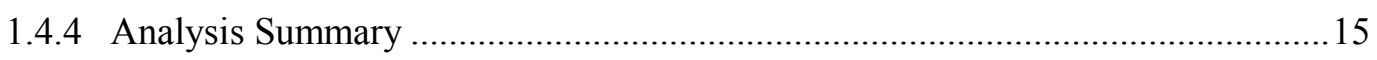

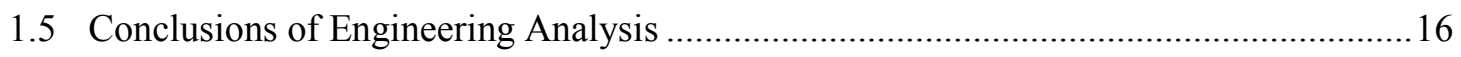

2.0 Biological Assessment of Consequences of Impact .......................................................... 17

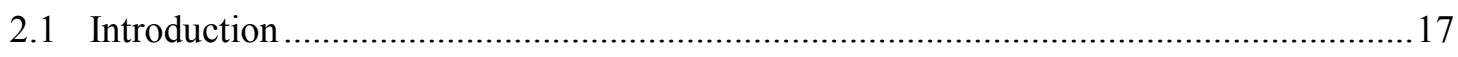

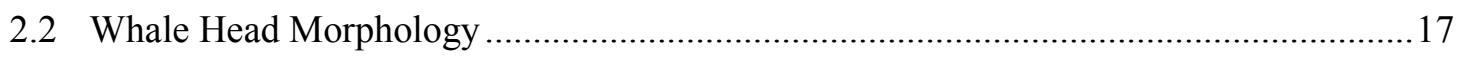

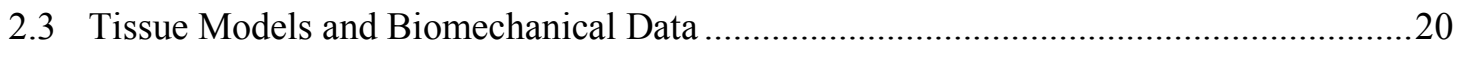

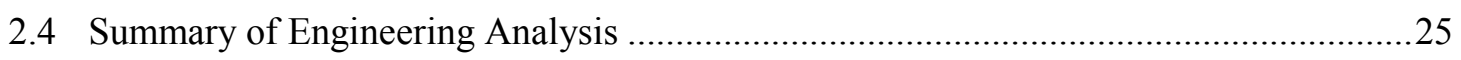

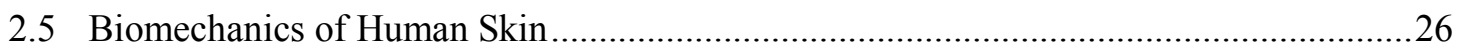

2.6 Consequence of Turbine Blade Impact on Whale Tissue ..........................................27

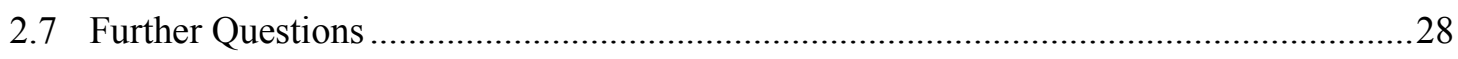

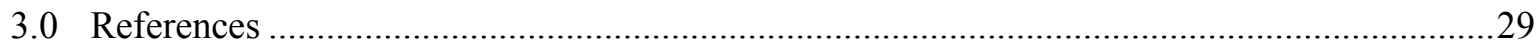




\section{Figures}

Figure 1. Front View of Blade with Spacing Dimensions of Blade Edges .......................................2

Figure 2. Isometric View with Spacing Between Blade Faces ......................................................2

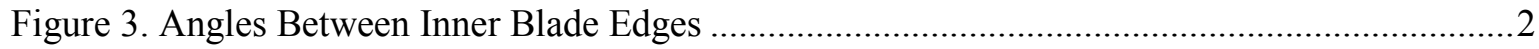

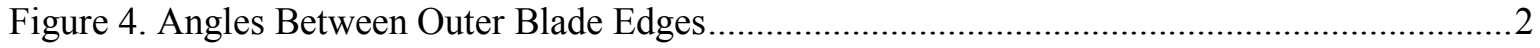

Figure 5. Probability Distribution of Velocity at Blade Tip ...........................................................

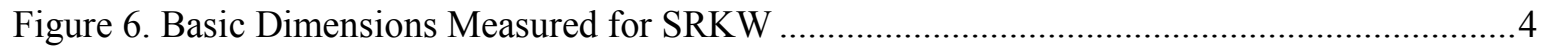

Figure 7. Maximum Reported for an Adult Male SRKW .........................................................

Figure 8. Plot of Probability Distribution for Velocity at a Location of $0.4 \mathrm{~m}$ from the Tip of the

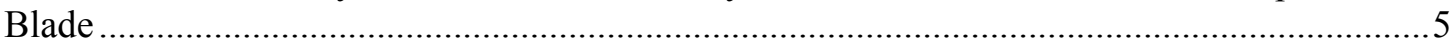

Figure 9. "Maximum Velocity" SRKW and Blade Impact Scenario Schematic ..............................6

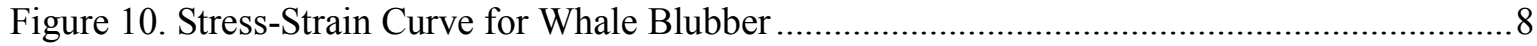

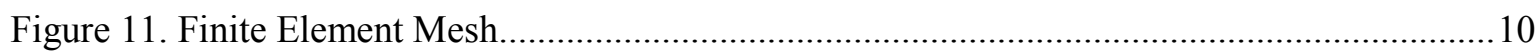

Figure 12. Finite Element Mesh - Impact Region................................................................... 10

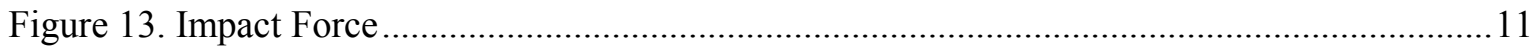

Figure 14. Strain, Standard Blade, $1 \mathrm{~m} / \mathrm{s}$ at Peak Load.............................................................. 12

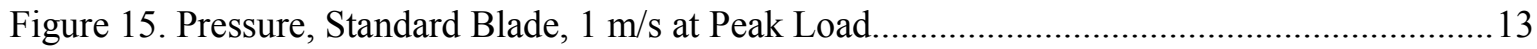

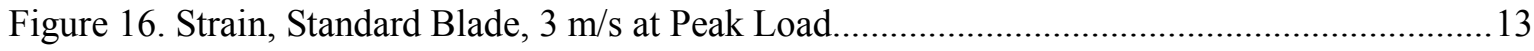

Figure 17. Pressure, Standard Blade, $3 \mathrm{~m} / \mathrm{s}$ at Peak Load.............................................................. 14

Figure 18. Maximum Strain (Log Strain) and Stress Verses Impact Velocity ............................... 15

Figure 19. A Sagittal CT Scan of the Head of an Adult Killer Whale ............................................ 18

Figure 20. CT Scan of a Transverse Slice Through the Head of a Killer Whale Approximately $40 \mathrm{~cm}$ from the Tip of the Whale's Snout.............................................................................. 19

Figure 21. Intensity Values Along a Vertical Transect Through a Transverse Slice of CT Scan

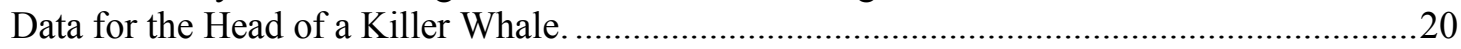

Figure 22. Description of Material Toughness in the Context of Stress-Strain Dynamics..............21

Figure 23. Structure of Whale Epidermis ...............................................................................23

Figure 24. Examples Stress-Strain Characteristics for Some Manmade Elastomers ......................23 


\section{Tables}

Table 1. Resultant Impact Velocity for $5 \mathrm{~m} / \mathrm{s}$ Blade Velocity Combined with a Range of Forward Velocities.

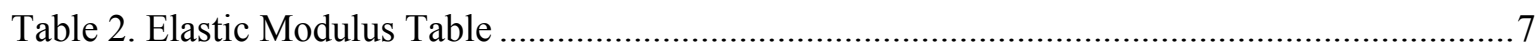

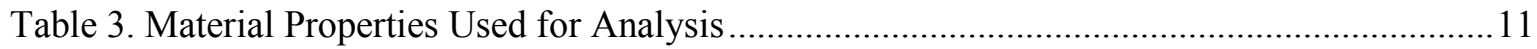

Table 4. Peak Stress and Strain from Computational Simulations ................................................. 12

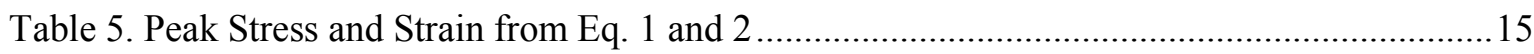

Table 6. Comparative Epidermal Ranges Reported for Baleen Whale Species..............................22

Table 7. Properties of Various Elastomers. ................................................................................24

Table 8. Table of the Mechanical Properties of Various Elastomers................................................25

Table 9. Copy of Table 5 from the Sandia Report of the Results of Engineering Analysis of the

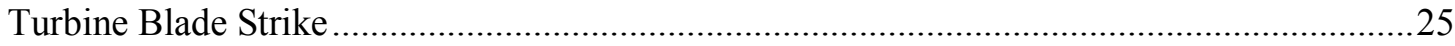





\subsection{Engineering Analysis of Impact}

\subsection{Introduction}

This section outlines the engineering analysis by Sandia National Labs in determining the stresses on a SRKW from a blade impact. The first portion of the work was to collect relevant geometry, mass, material, and speed characteristics of the OpenHydro Turbine, rotor, and blade. Next, estimated dimensions and material properties for the SRKW were determined along with possible impact scenarios for the study. Finally, the model simulation method and set-up are described.

\subsection{Geometry and Operational Characteristics of OpenHydro Turbine}

Relevant information was gathered on the geometry and operation of the OpenHydro turbines to be deployed in Puget Sound by:

a. Obtaining design drawings with the necessary details of the blade assembly and rotor for the OpenHydro turbine. Key details include the number, location, shape, and angle of the blades, with dimensions of the leading edge of the blades.

b. Obtaining information on the materials and construction detail of the turbine blade assembly and rotor to compute blade mass and other physical properties.

c. Obtaining information on the operating characteristics of the turbine including $\mathrm{rpm} / \mathrm{blade}$ speed at the range of tidal flows expected in Admiralty Inlet.

All of the above data was supplied by OpenHydro with assistance from the University of Washington and is summarized below. It should be noted that designs are not finalized and some parameters such as materials and moment of inertia are proprietary. In these cases, estimates are used based on consultation with Open Hydro. Overall, the dimensions and material properties supplied by OpenHydro were sufficient for the analysis.

\subsubsection{Design Parameters and Drawings}

Figures Figure 1 and Figure 2 along with Figure 3 and Figure 4 show the relevant drawings for blade spacing and angles. The turbine diameter is $4.8 \mathrm{~m}$ and the mass is $6,200 \mathrm{~kg}$. 


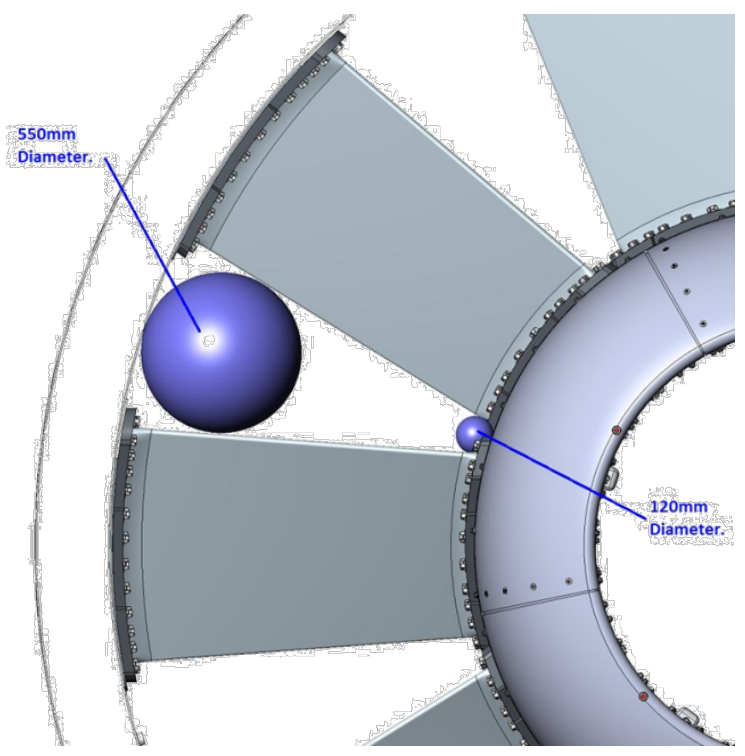

Figure 1. Front View of Blade with Spacing Dimensions of Blade Edges

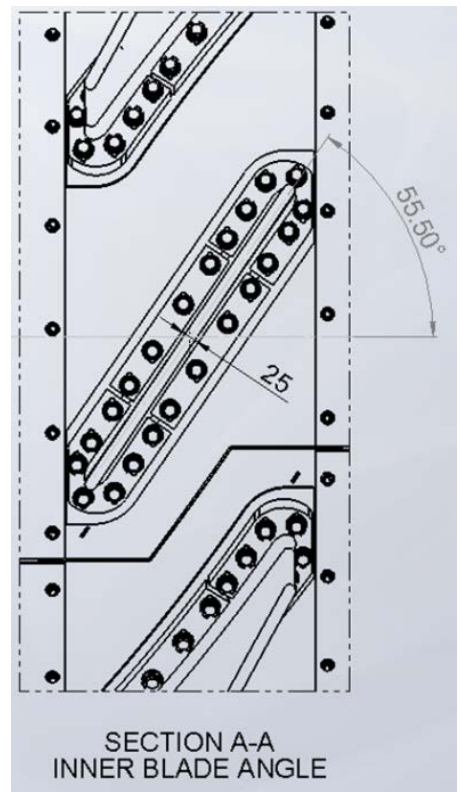

Figure 3. Angles Between Inner Blade Edges

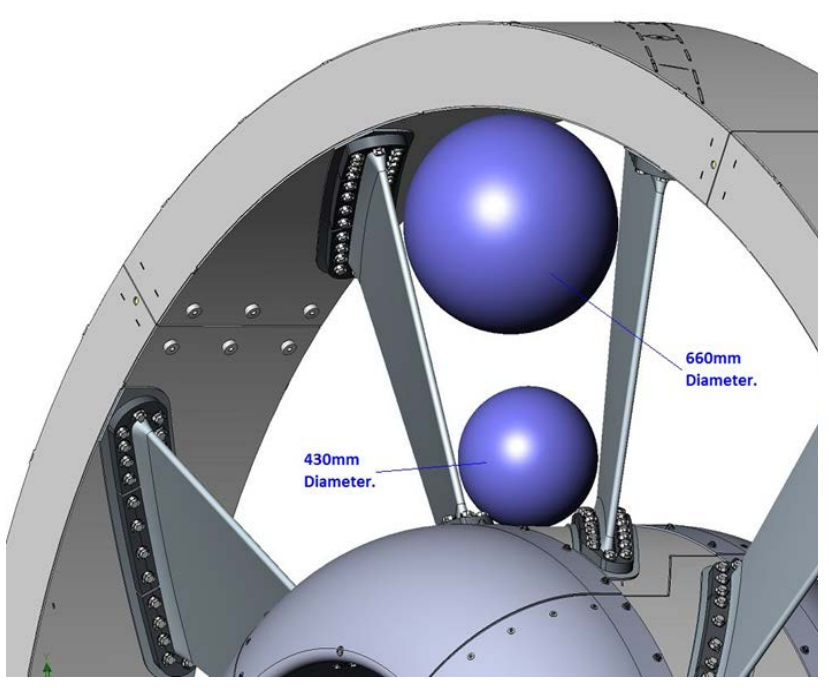

Figure 2. Isometric View with Spacing Between Blade Faces

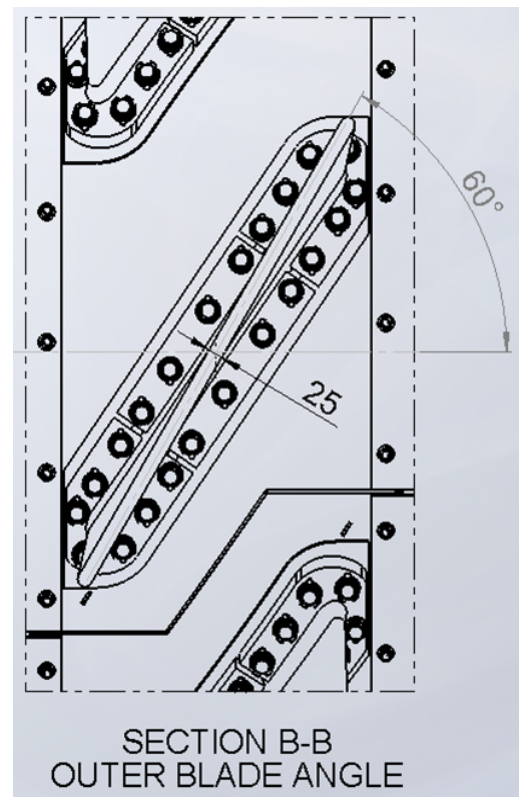

Figure 4. Angles Between Outer Blade Edges

\subsubsection{Turbine and Blade Material Properties}

Based on communications with OpenHydro, the blade material properties could be adequately estimated using a stiff plastic or composite material. Using either fiberglass composite or plastic resin 
such as Delrin would be adequate because either is far stiffer than the SRKW material properties. An elastic modulus (material property defined as stress over strain for elastic deformation under an applied force) of $7 \mathrm{kPa}$ was chosen for the blade based on information provided by OpenHydro.

The moment of inertia for the turbine could be adequately estimated assuming the rotor is a solid disc with a mass of $6,200 \mathrm{~kg}$ and diameter of $4.8 \mathrm{~m}$. Note the full turbine diameter is $6 \mathrm{~m}$ while the furthest extent of the blade is $4.8 \mathrm{~m}$.

\subsubsection{Rotor Rotation Rates and Blade Speed}

From the information supplied by OpenHydro, and the expected tidal velocities within the Admiralty Inlet deployment site, the blade velocities can be calculated anywhere along the radius of the blade edge. Figure 5 shows the probabilities for the velocity at the blade tip which is the maximum velocity possible. Note that this is not an expected impact location for an SRKW. The maximum expected impact scenario is discussed in the following section.

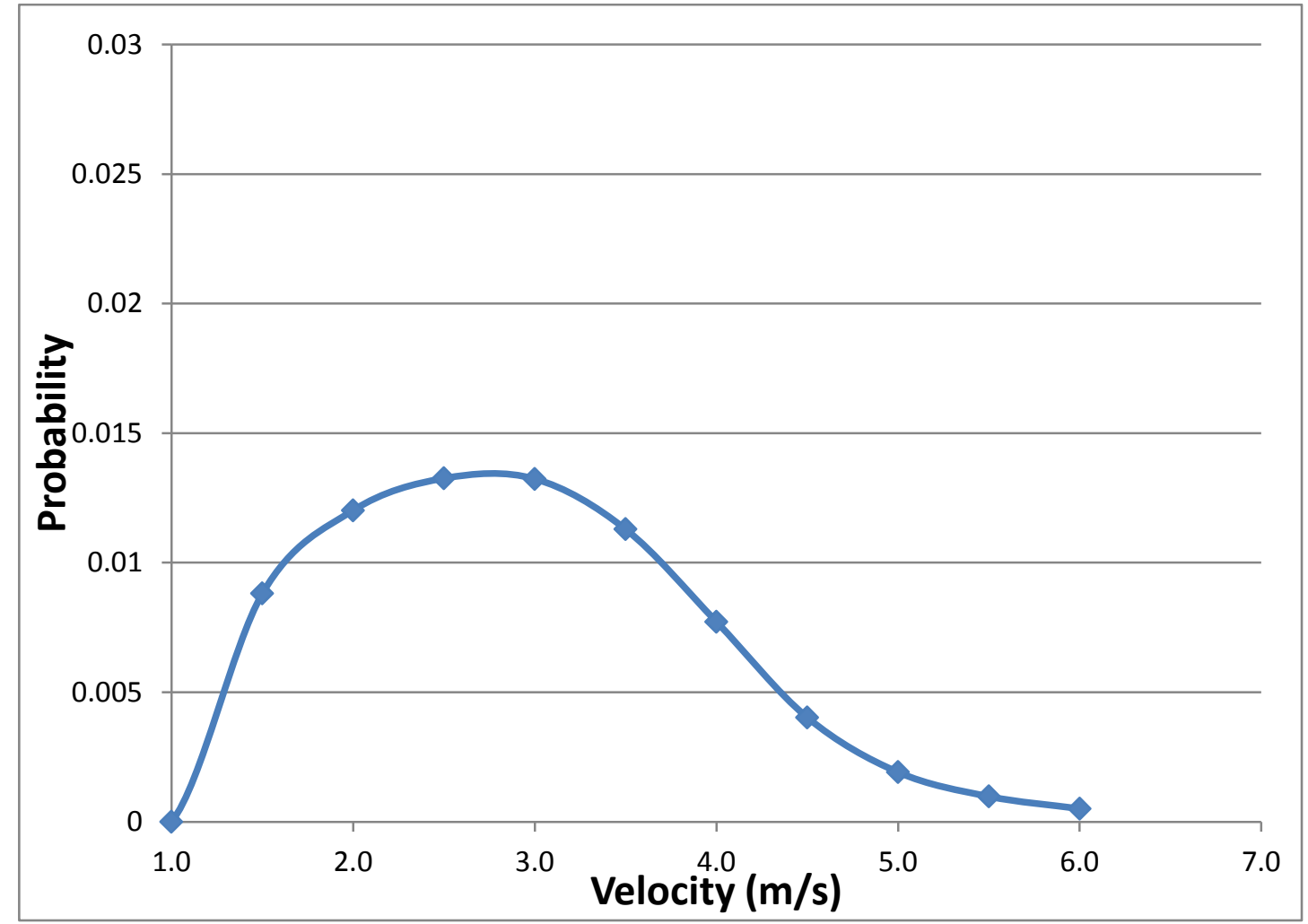

Figure 5. Probability Distribution of Velocity at Blade Tip. Note that about 26 percent of the time, the blade is stationary which is not shown here.

\subsection{Geometry and Characteristics of a SRKW}

\subsubsection{Geometry of SRKW}

A recent publication from Durban et al., 2009 contains field data for adult male SRKWs. An adult male was chosen because it has the most mass and thus forces the tissue affected by the impact to absorb 
a larger amount of the energy with less momentum exchange being converted to moving the whale mass. The largest adult male reported by Durban et al. was used for conservatism. Figure 6 shows the primary dimensions of head, breadth, and length from largest adult male measured in Durban et al., 2009 (without tail section).

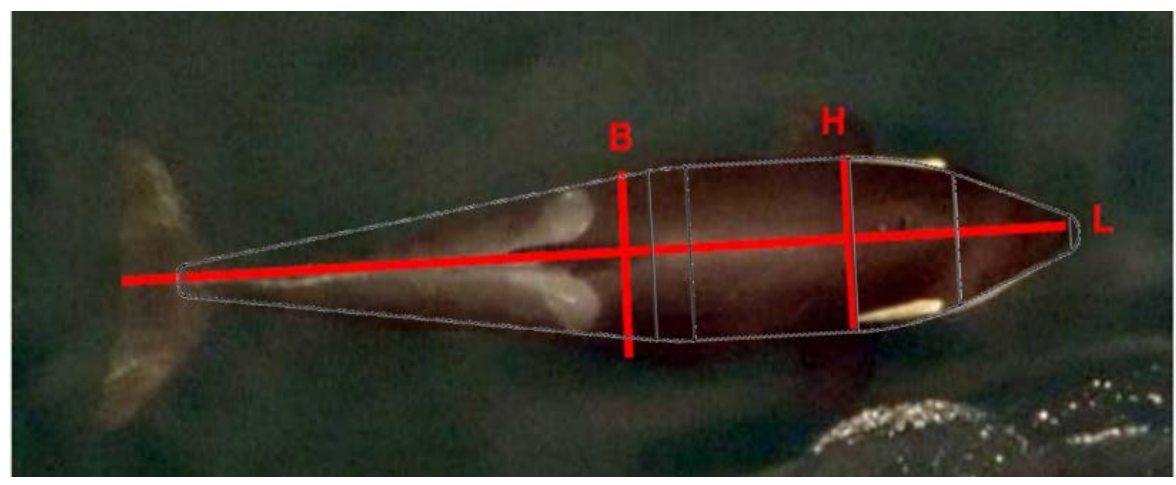

Figure 6. Basic Dimensions Measured for SRKW (Durban et al., 2009)

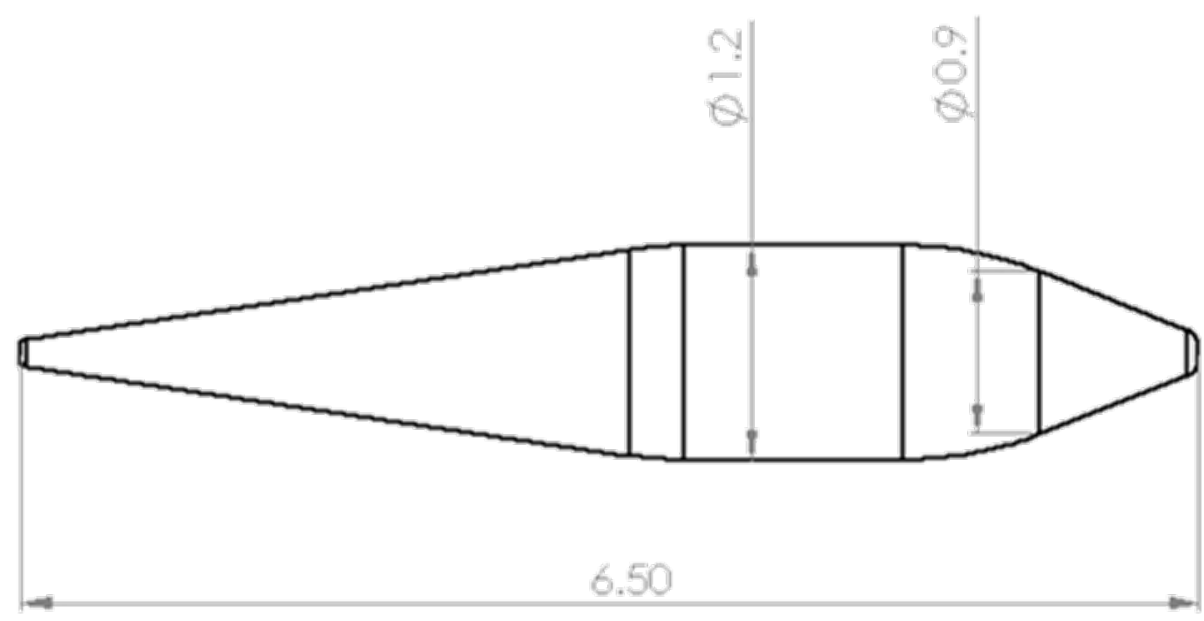

Figure 7. Maximum Reported for an Adult Male SRKW

The mass associated with the largest size of an adult, male SRKW was very near 4,000 $\mathrm{kg}$ and will be approximated as such for analysis.

\subsubsection{Blade Impact Scenarios}

It will be difficult, if not impossible, for an adult SRKW to impact the blade at the furthest radius from the center of rotation due to geometry limitations of the turbine and whale. Therefore, the blade velocity used was at the location where the head of the whale could be inserted the furthest into the turbine rotor (reference to cross section radii in Figure 7). This causes the most absorption by the tissue due to impact and is the most conservative scenario. Remember from above that the most severe impact with respect to tissue damage would be for a large mass (i.e., adult male) to be hit as close to its center of mass as possible. This forces the tissue to mitigate more of the impact rather than simply just moving the mass (whale) out of the way. 
In summary, the most severe case for tissue impact mitigation is when the nose of an adult SRKW fits perfectly between the blades at the furthest most radii. This is approximately $0.4 \mathrm{~m}$ from the tip of the SRKW nose and at a $2.0 \mathrm{~m}$ radius on the blade. The probability distribution as a function of blade velocity is demonstrated in Figure 8.

A much smaller, juvenile SRKW was also examined with regard to comparative geometry and momentum transfer. In this case, the smaller head of the juvenile SRKW allows for a further radius of the blade to make impact and impart velocities about 10 percent higher than what an adult would experience. However, this is largely overshadowed by the much reduced mass of the juvenile $(\sim 500 \mathrm{~kg})$ compared to the adult $(\sim 4,000 \mathrm{~kg})$. Basic physics dictates that momentum is determined solely by velocity and mass (momentum $=\mathrm{mv})$ of the objects and each of these quantities has equal weight in determining transfer of momentum between colliding objects. Therefore, a 10 percent increase in blade velocity is outweighed by an 800 percent reduction in mass. It follows that the momentum transfer to motion of the juvenile would be at least 7 times more than compared to an adult meaning that the impact to the tissue should be at least 7 times less for a juvenile SRKW. So, unless juvenile SRKW tissue is more than 7 times sensitive to impact force, the impact case for an adult male SRKW is, by far, the most severe.

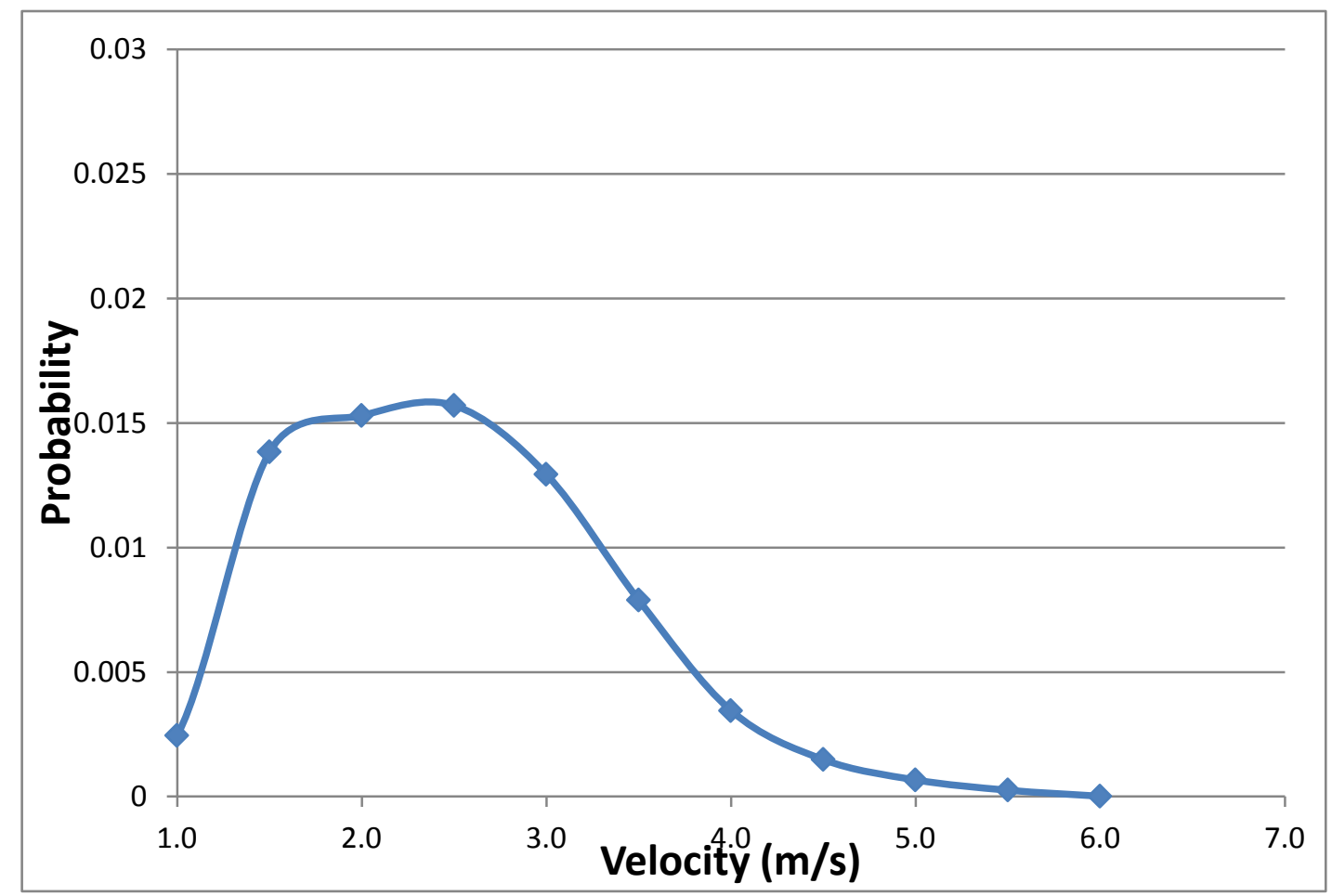

Figure 8. Plot of Probability Distribution for Velocity at a Location of $0.4 \mathrm{~m}$ from the Tip of the Blade. Note that about 26 percent of the time, the blade is stationary which is not shown here. 


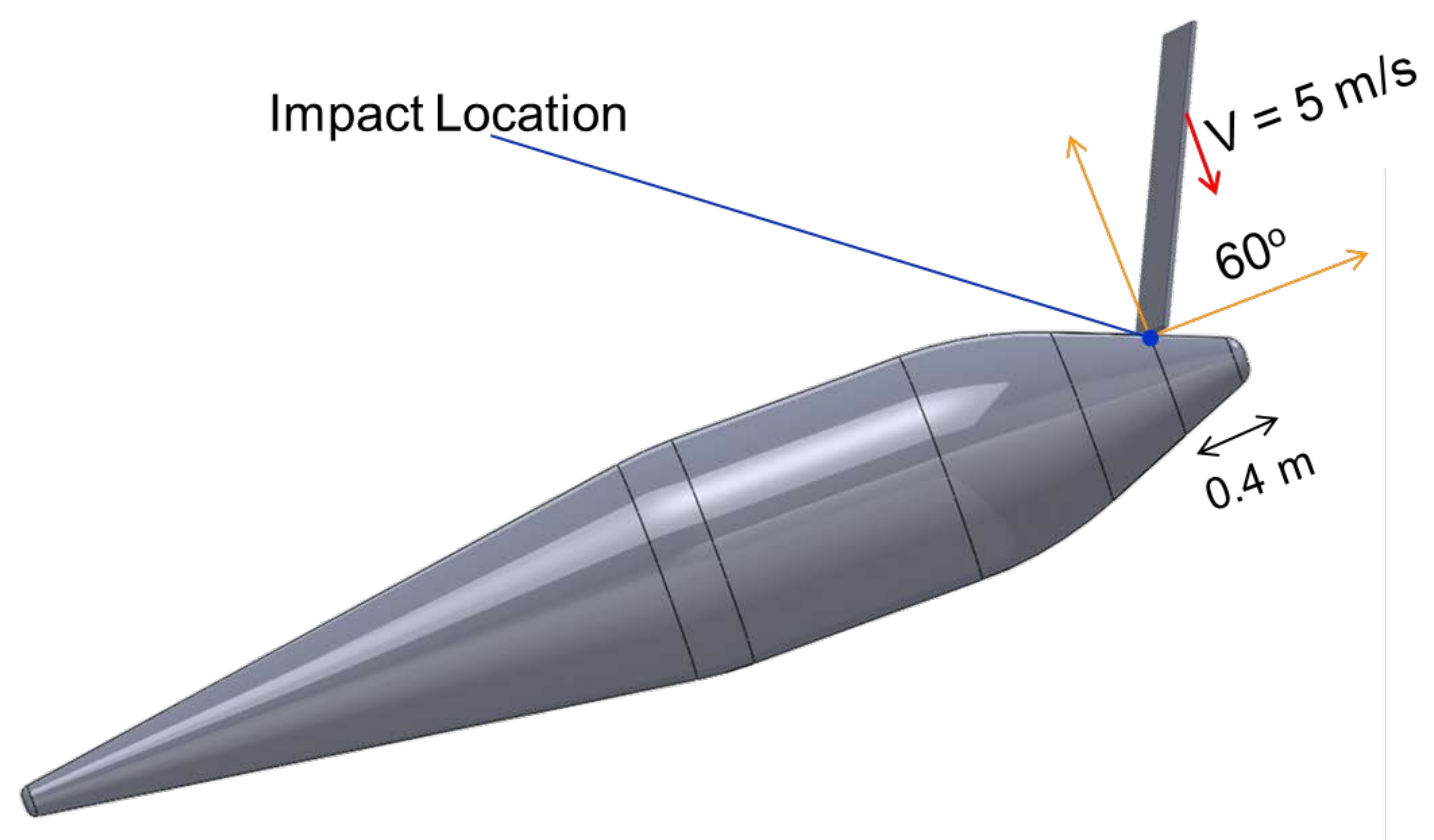

Figure 9. "Maximum Velocity" SRKW and Blade Impact Scenario Schematic

Other cases were considered for rough analysis estimates but have been discarded due to the gross lack of realism in the scenario. These are:

1. A very generalized and conservative closed form solution. This would have a fixed "whale" mass upon impact and include only a single elastic modulus for the whale tissue (blubber).

2. FEA model using blade and whale models from Figure 9 and a variable elastic modulus for whale tissue (blubber). The whale model will be fixed and thus force the tissue to absorb the impact.

The primary problem with the above scenarios is the overly simplistic "fixing" of the SRKW mass. The "fixed" scenario forces the SRKW tissue to absorb all the impact which is grossly incorrect since the body is, in reality, free to both translate and rotate away from the impact point. The fact that the impact location on the SRKW is a great distance from the center of gravity of the body $(\sim 2-3 \mathrm{~m})$ also means that momentum transfer into rotation is significant in this case and should not be excluded from the analysis.

One could also analyze the inclusion of the forward motion of the SRKW by determining the threshold velocity for ramming versus that of curious inspection upon impact with the blade. The blade and forward motion of the SRKW are basically perpendicular, meaning that the resultant velocity vector can be calculated easily using the Pythagorean theorem. Table 1 shows the resulting blade impact velocity for a range of forward velocities when the blade is moving at $5 \mathrm{~m} / \mathrm{s}$ : 
Table 1. Resultant SRKW Impact Velocity for $5 \mathrm{~m} / \mathrm{s}$ Blade Velocity Combined with a Range of Forward Velocities

\begin{tabular}{|c|c|}
\hline $\begin{array}{c}\text { Forward Velocity } \\
(\mathbf{m} / \mathbf{s})\end{array}$ & $\begin{array}{c}\text { Resultant Impact Velocity } \\
\text { Vector }(\mathbf{m} / \mathbf{s})\end{array}$ \\
\hline 1 & 5.1 \\
\hline 2 & 5.4 \\
\hline 3 & 5.8 \\
\hline 4 & 6.4 \\
\hline 5 & 7.1 \\
\hline 6 & 7.8 \\
\hline 7 & 8.6 \\
\hline 8 & 9.4 \\
\hline 9 & 10.3 \\
\hline 10 & 11.2 \\
\hline
\end{tabular}

As one can see from Table 1, once the forward velocity starts to significantly ( $>10$ percent increase) affect the resultant velocity where it is well above the maximum blade velocity of $5 \mathrm{~m} / \mathrm{s}$, it is approaching what might be expected as a ramming scenario (forward velocity $>3 \mathrm{~m} / \mathrm{s}$ ). Previous meetings and discussions have discounted the ramming scenario (in which a SRKW collides with the turbine while swimming at top speed) and the only cases that seem to accommodate an "inspection" velocity are in the $\sim 3 \mathrm{~m} / \mathrm{s}$ range or less for the forward velocity of the SRKW (Noren, 2011). The additional computational resources necessary to model both masses (blade and SRKW) moving do not seem warranted for a possible increase in velocity that is around 10 percent. Instead, this scenario will be extrapolated from "blade velocity only" simulations.

\subsubsection{Material Properties for SRKW}

Material properties for a Cuvier's Beaked whale are available via tissue sample testing and CT scanning from Soldevilla et al., 2005. Table 2 shows the elastic modulus for several tissue types.

Table 2. Elastic Modulus Table (Soldevilla et al., 2005)

\begin{tabular}{|c|r|r|r|r|r}
\hline & \multicolumn{3}{|c|}{ Forehead tissues } & \multicolumn{2}{c}{ Mandible tissues } \\
\hline $\begin{array}{c}\text { Stress } \\
(\mathrm{kPa})\end{array}$ & Blubber & Acoustic fat & $\begin{array}{c}\text { Connective } \\
\text { tissue }\end{array}$ & Blubber & Acoustic fat \\
\hline 2.5 & 59 & 75 & 124 & 158 & 78 \\
\hline 5 & 208 & 153 & 149 & 220 & 215 \\
\hline 10 & 411 & 212 & 279 & 400 & 303 \\
\hline 20 & 712 & 412 & 618 & 650 & 420 \\
\hline 30 & 1006 & 626 & 1030 & 913 & 587 \\
\hline 40 & 1200 & 739 & 1295 & 991 & 726 \\
\hline 50 & 1410 & 910 & 1510 & 1174 & 934 \\
\hline
\end{tabular}

These stresses are somewhat lower than what is expected for the impact scenario analysis and extrapolation may be required to determine the elastic modulus at higher stress states. Figure 10 shows the curve developed by Soldevilla et al., 2005 for stress vs. strain of the whale blubber. This figure regarding the strain relationship for each tissue sample suggests that the strain and stress reach an 
asymptote near $1,800 \mathrm{kPa}$. In addition, the blubber and connective tissue have very similar elastic moduli and the same value could be reasonably used to represent each. Therefore, as a conservative estimate, $1,800 \mathrm{kPa}$ will be used for the elastic modulus of all "non-bone" tissues in the head region.

Data provided by PNNL for the structure of the head region from McKenna, 2005 provides sufficient detail to reconstruct the dimensions of bone matter in the head for use in the model analysis. The material properties of the bone matter can be extracted from Table 4.5 in Campbell-Malone, 2007. There are several values for elastic moduli of Right Whale mandible bone in Table 4.5 as a function of direction. The average value is approximately $300 \mathrm{MPa}$ for both directional and bone type (trabecular or cortical), which was used for model analysis.

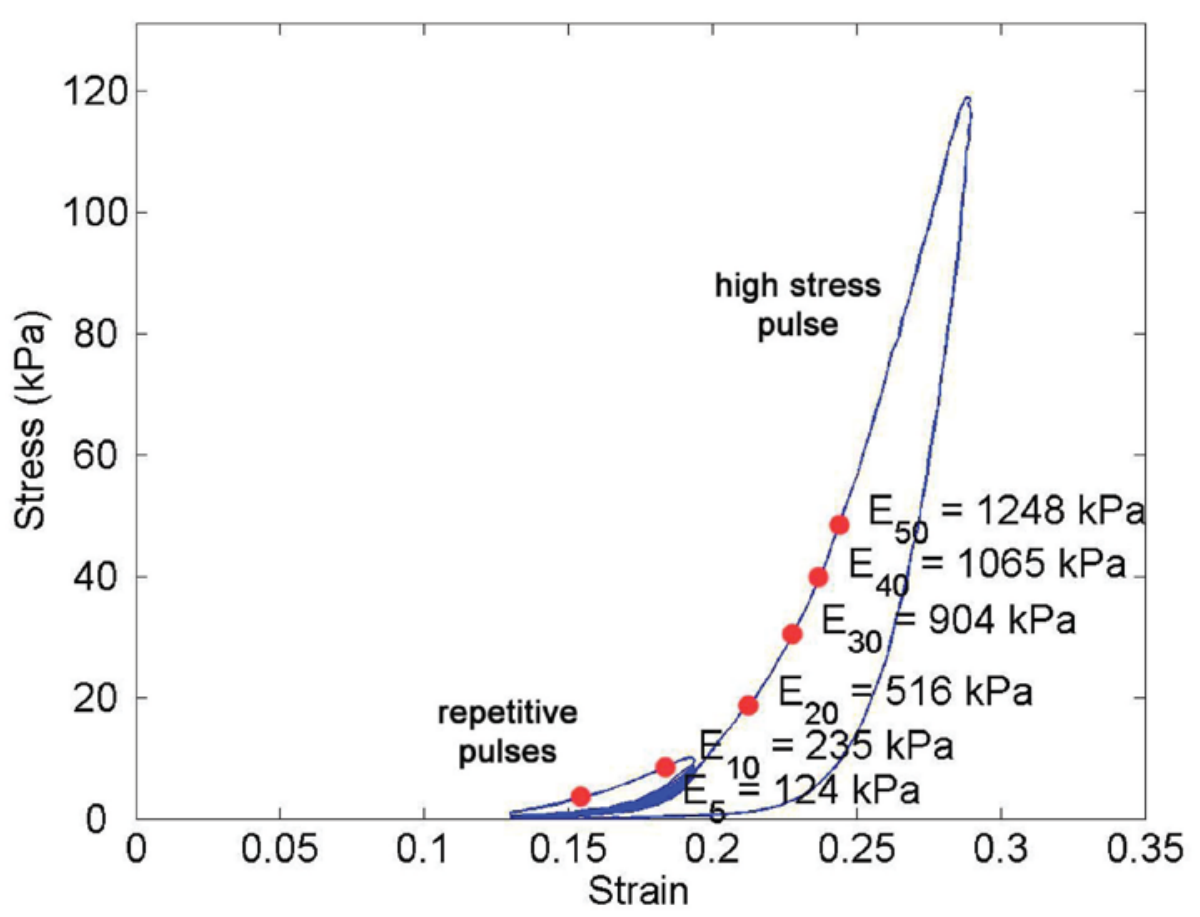

Figure 10. Stress-Strain Curve for Whale Blubber (Soldevilla et al., 2005)

\subsection{Analysis with Finite Element Model}

\subsubsection{Model Set-up}

Closed form solutions are available for certain impact scenarios. However, the large deformations and the evolving nature of the contact interface for a blade striking a large mammal suggest the need for a finite element analysis. Figure 11 and Figure 12 show the model created for this study. Note that a symmetry plane is also employed to reduce the model size. The dimensions are based on killer whale images shown in Figure 6 and represent a $4000 \mathrm{~kg}$ adult male. The turbine rotor is represented by a single blade (shown in light blue) that is constrained to move in one direction. The ballast elements on the end of the blade (shown in dark blue) are given a very large density so the linear momentum of this massive 
$(4460 \mathrm{~kg}$ ) blade corresponds to the angular momentum of the rotor. The skin, blubber, and bone are shown in black, red, and green, respectively. For this study, the skin has the same properties as the blubber. The model domain does not include the surrounding water and omitting the water is expected to have a modest effect on the peak loads and it significantly reduces the model size and complexity. Including the surrounding water in the domain necessitates significantly more computational resources than are currently available with the funding and schedule restraints of the project. In short, the average magnitude of the velocity for the whale body upon impact is quite slow ( $\sim 1 \mathrm{~m} / \mathrm{s}$ or less) and the drag forces in water are $F=1 / 2 \mathrm{~A} \mathrm{C}_{\mathrm{D}} \square \mathrm{V}^{2}$, with $\mathrm{C}_{\mathrm{D}}$ (drag coefficient) being approximately 1 for a cylindrical shape. This means the restraining forces by the water on the body are a few hundred pounds, which is quite small in comparison to the average $9,000 \mathrm{lbs}(4,000 \mathrm{~kg})$ of an adult SRKW. Therefore the surrounding water should not be a large effect at these speeds.

Table 3 lists the material properties used for this study. All materials are treated as linear elastic since the available material data is limited. The elastic modulus of the blubber is based on the slope of a stressstrain curve (Figure 10) at the maximum value (120 kPa). The Poisson's ratio for the nearly incompressible blubber and bone were chosen to match the measured sound speeds. The blubber and bone materials use a Neo-Hookean constitutive model that is valid for large deformations.

More complex material models could be utilized provided actual test data for the skin and blubber was available. Highly elastic materials such as skin, blubber, and rubber respond differently in tension and compression and the load-deflection behavior can be very nonlinear. These materials can be represented with a hyperelastic constitutive model such as the Mooney-Rivlin model available in in the Sandia code, Presto (Koteras et al., 2006). These models have parameters which must be determined by testing specimens under different loading conditions (tension, compression, and shear). The tests are then analyzed with the chosen parameters to ensure the fit adequately represents the measured behavior. Some finite element codes automate the process and accept various types of test data and determine the parameters for the selected constitutive model. However, the necessary data described above are not available for skin, blubber, or rubber and a linear elastic treatment was employed instead. 


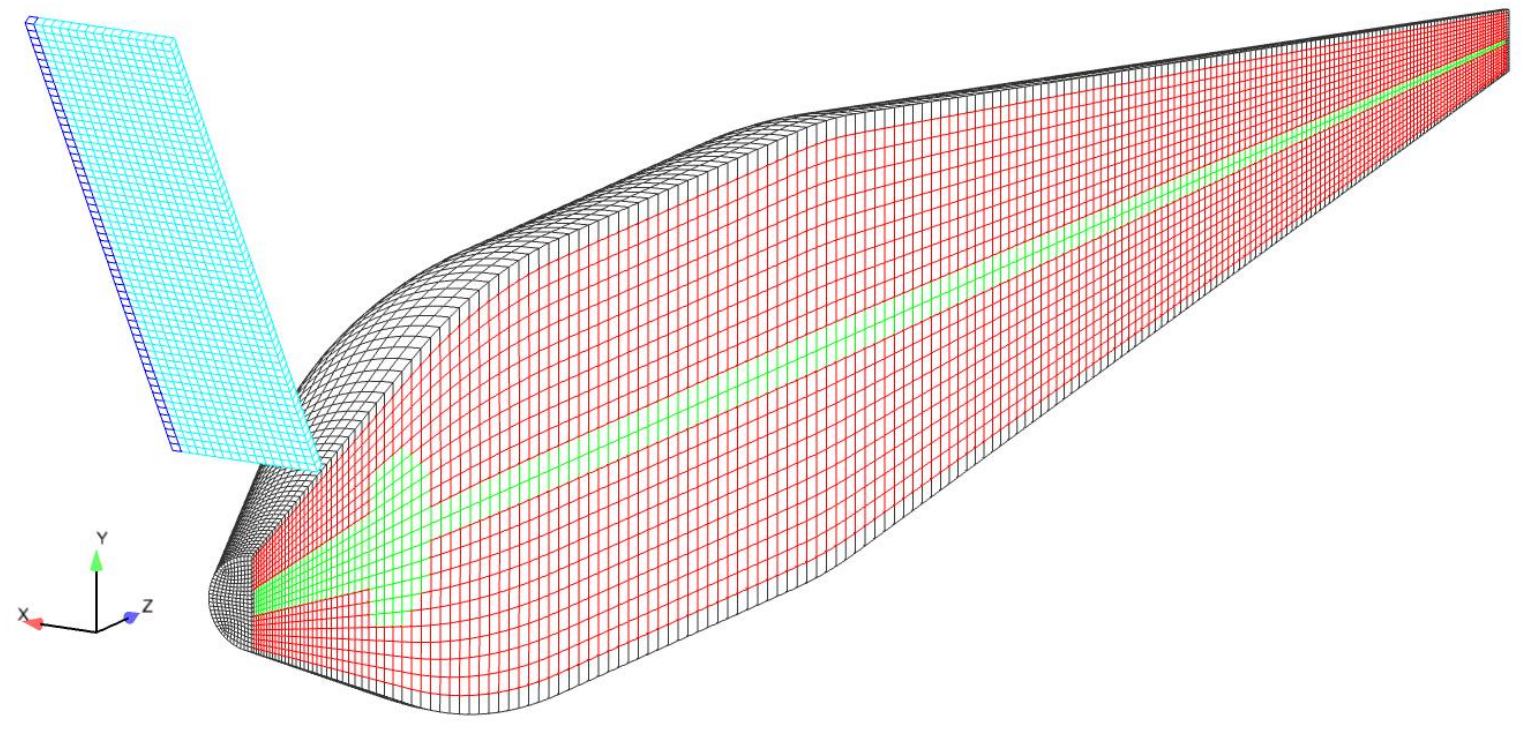

Figure 11. Finite Element Mesh

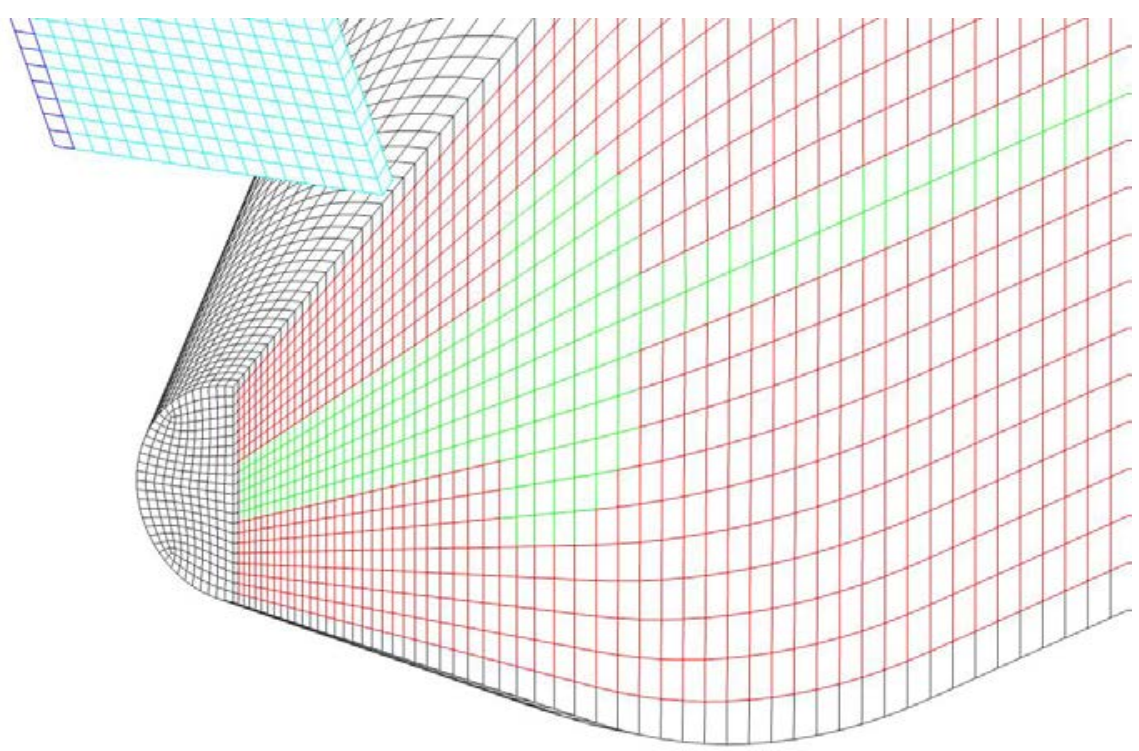

Figure 12. Finite Element Mesh - Impact Region 
Table 3. Material Properties Used for Analysis

\begin{tabular}{|c|c|c|c|}
\hline Material & Elastic Modulus (MPa) & Density (kg/m3) & Poisson's Ratio \\
\hline Blubber* & 1.8 & 1000 & 0.4998 \\
\hline Bone* & 300 & 1000 & 0.4745 \\
\hline Blade & 7000 & 1200 & 0.3 \\
\hline Ballast & 7000 & 2325100 & 0.3 \\
\hline
\end{tabular}

* Blubber and bone constitutive models are valid for large deformations.

\subsubsection{Impact Analysis Results}

The transient dynamics code Presto was used to consider impact speeds of 1 to $5 \mathrm{~m} / \mathrm{s}$. This range is based on the shapes of the MHK device and a SRKW as well as the expected range of the rotor's angular speeds. In these simulations, the heavy blade is given an initial velocity and its edges are allowed to translate, but not rotate. The blade slows a small amount as it pushes the whale out of the way. Figure 13 shows the force-time histories for several cases. Due to element distortion issues, the simulations with the standard blade could not run to completion for speeds greater than $3 \mathrm{~m} / \mathrm{s}$. This is a computational artifact and doesn't necessarily indicate tissue damage. It occurred because large shear deformations caused an element nearest the impact to invert. To get results at higher impact speeds, a cylinder was added to the end of the blade. This particular modification may not be practical, but it is instructive. As shown in Figure 13, the modified blade loads the whale in a similar fashion. However, the distributed contact reduces the localized shear deformations in the tissue and allows higher impact speeds to be considered.

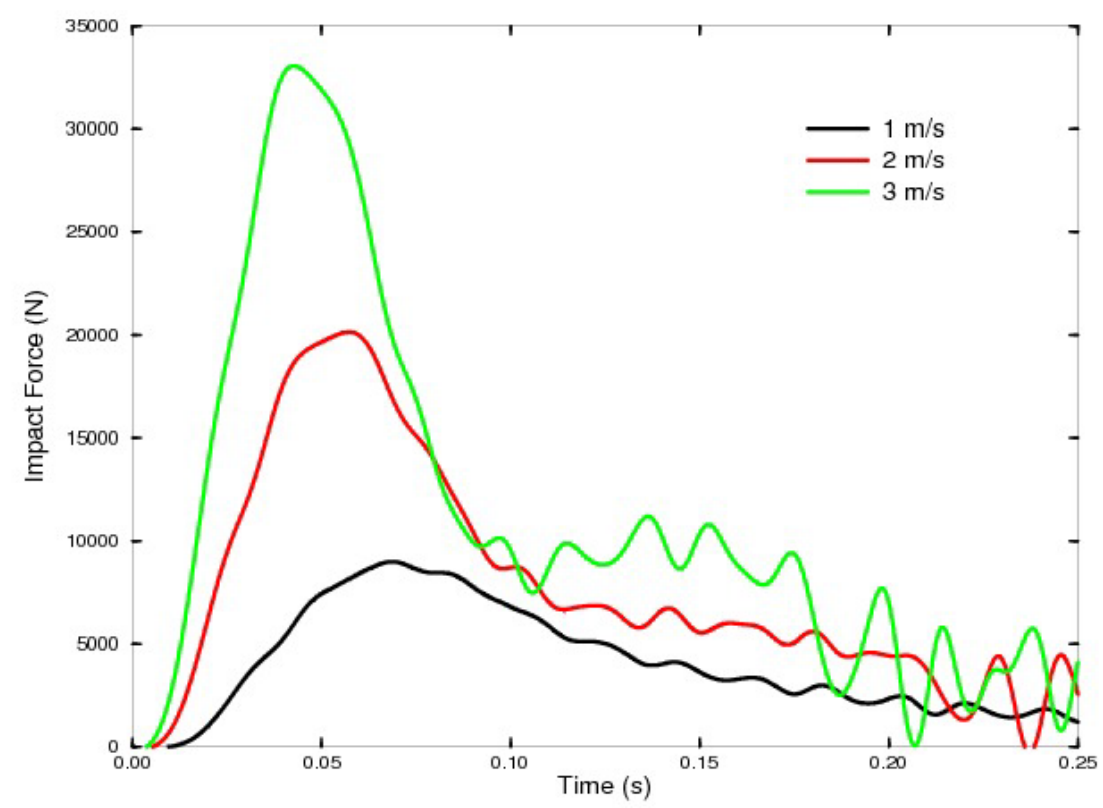

Figure 13. Impact Force

Figures 14 to 17 show the strain and pressure contours in the blubber and skin at approximately the peak load for two impact velocity cases of 1 and $3 \mathrm{~m} / \mathrm{s}$. Table 4 shows the peak stress and strain for each simulation. Although the images in these figures show what appears to be dramatic depression of the 
tissue and the maximum principal (logarithmic) strains would cause tearing in many structural materials (steel, glass composites, etc.), these levels would be quite acceptable for materials like human skin, tissue or natural rubber. For comparison, one could produce similarly proportional depression and strain (with little discomfort) as shown in Figure 14 through Figure 17 by simply pressing their index finger into their thigh.

Table 4. Peak Stress and Strain from Computational Simulations

\begin{tabular}{|c|c|c|c|}
\hline Blade Speed (m/s) & Blade Type & Maximum Principal Log Strain & Maximum Pressure (kPa) \\
\hline 1 & Standard & 0.26 & 950 \\
\hline 2 & Standard & 0.41 & 1650 \\
\hline 3 & Standard & 0.57 & 2340 \\
\hline 4 & Standard & $\mathrm{n} / \mathrm{a}$ & $\mathrm{n} / \mathrm{a}$ \\
\hline 5 & Standard & $\mathrm{n} / \mathrm{a}$ & $\mathrm{n} / \mathrm{a}$ \\
\hline
\end{tabular}

It should be noted that the peak strains and pressures listed in Table 4 occur in small volumes of tissue and are affected by the element size. Nevertheless, it is reasonable to compare results for different speeds and blade types since the same whale model was used for all of the simulations.

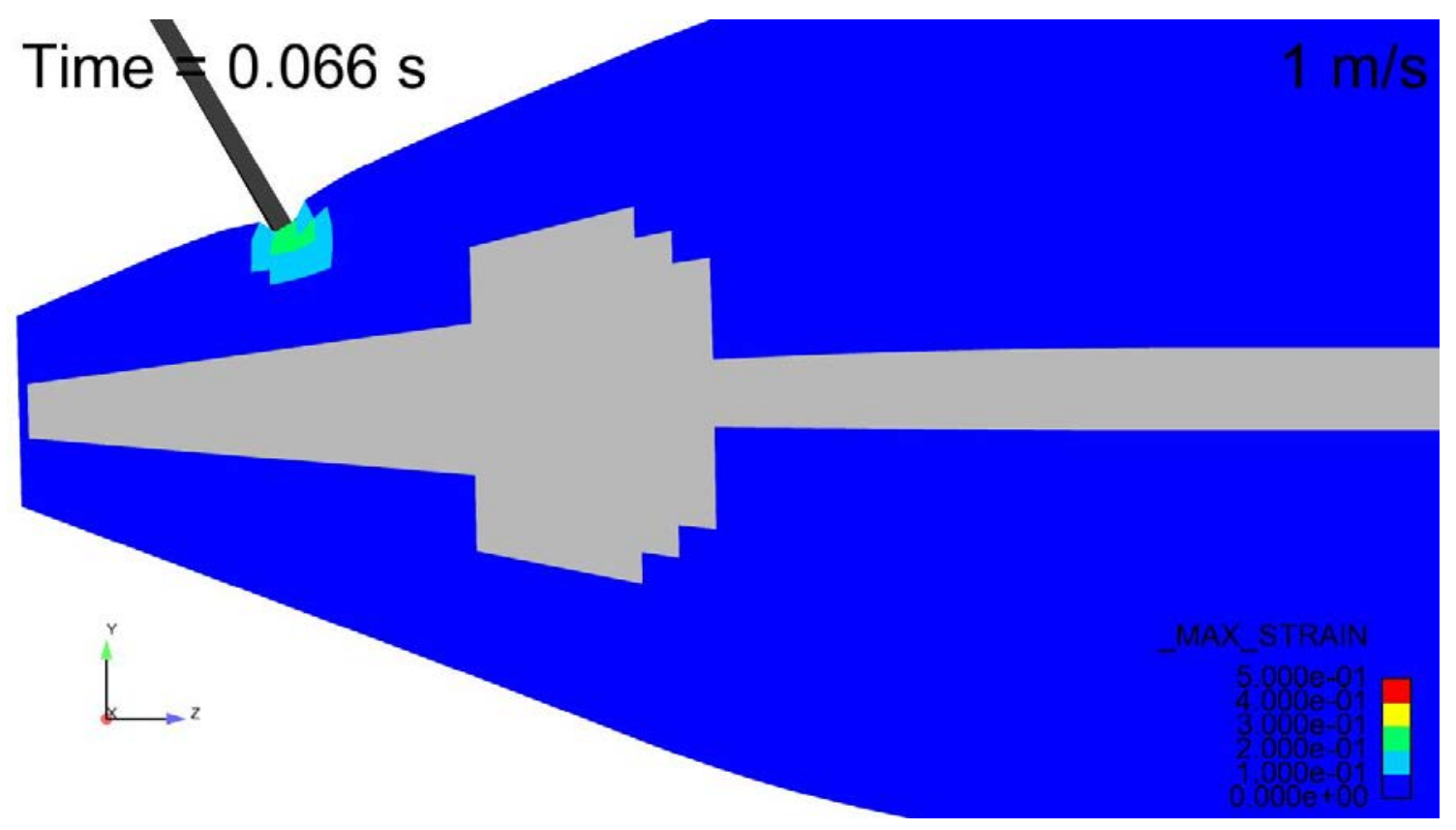

Figure 14. Strain, Standard Blade, $1 \mathrm{~m} / \mathrm{s}$ at Peak Load 


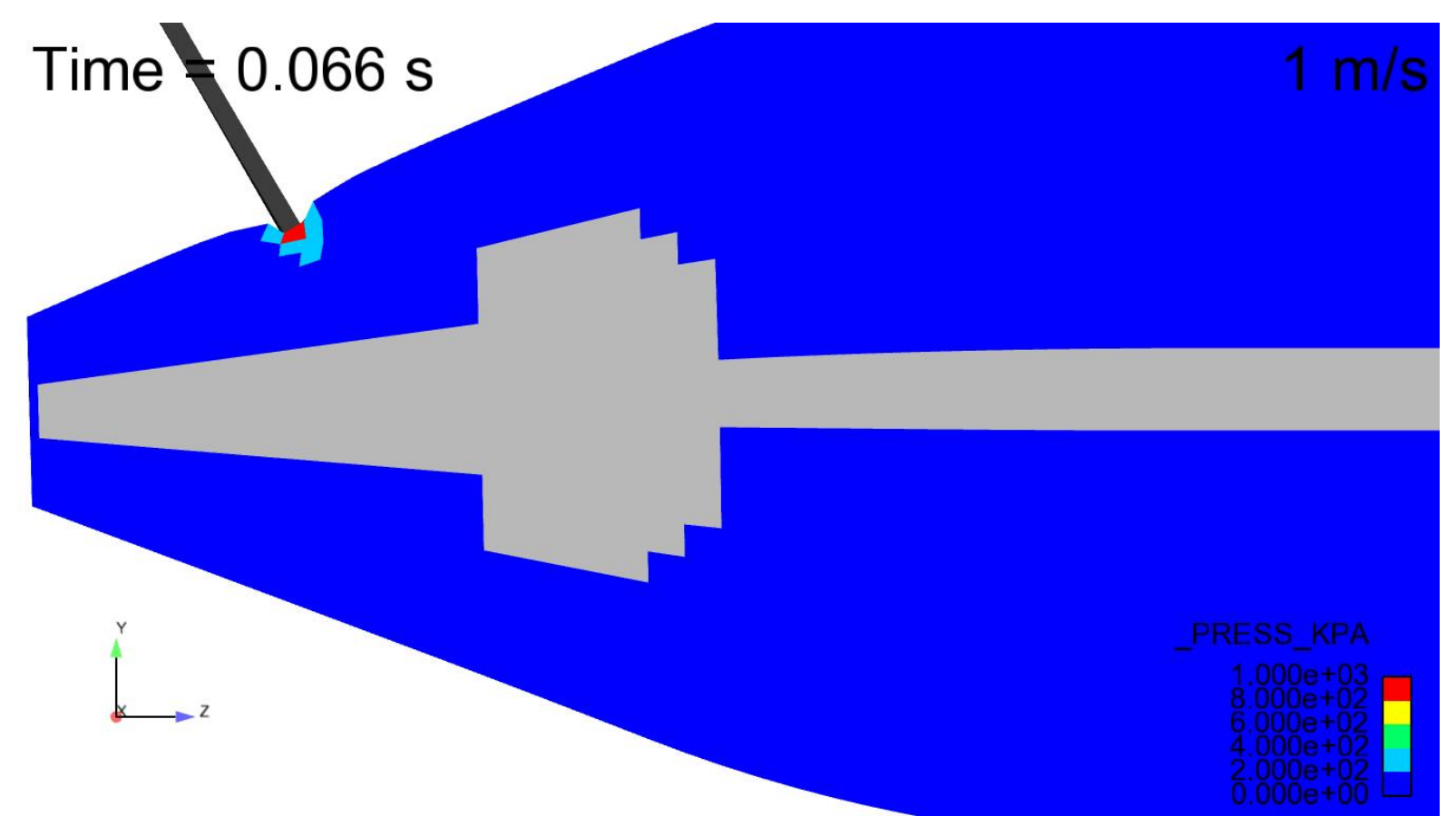

Figure 15. Pressure, Standard Blade, $1 \mathrm{~m} / \mathrm{s}$ at Peak Load

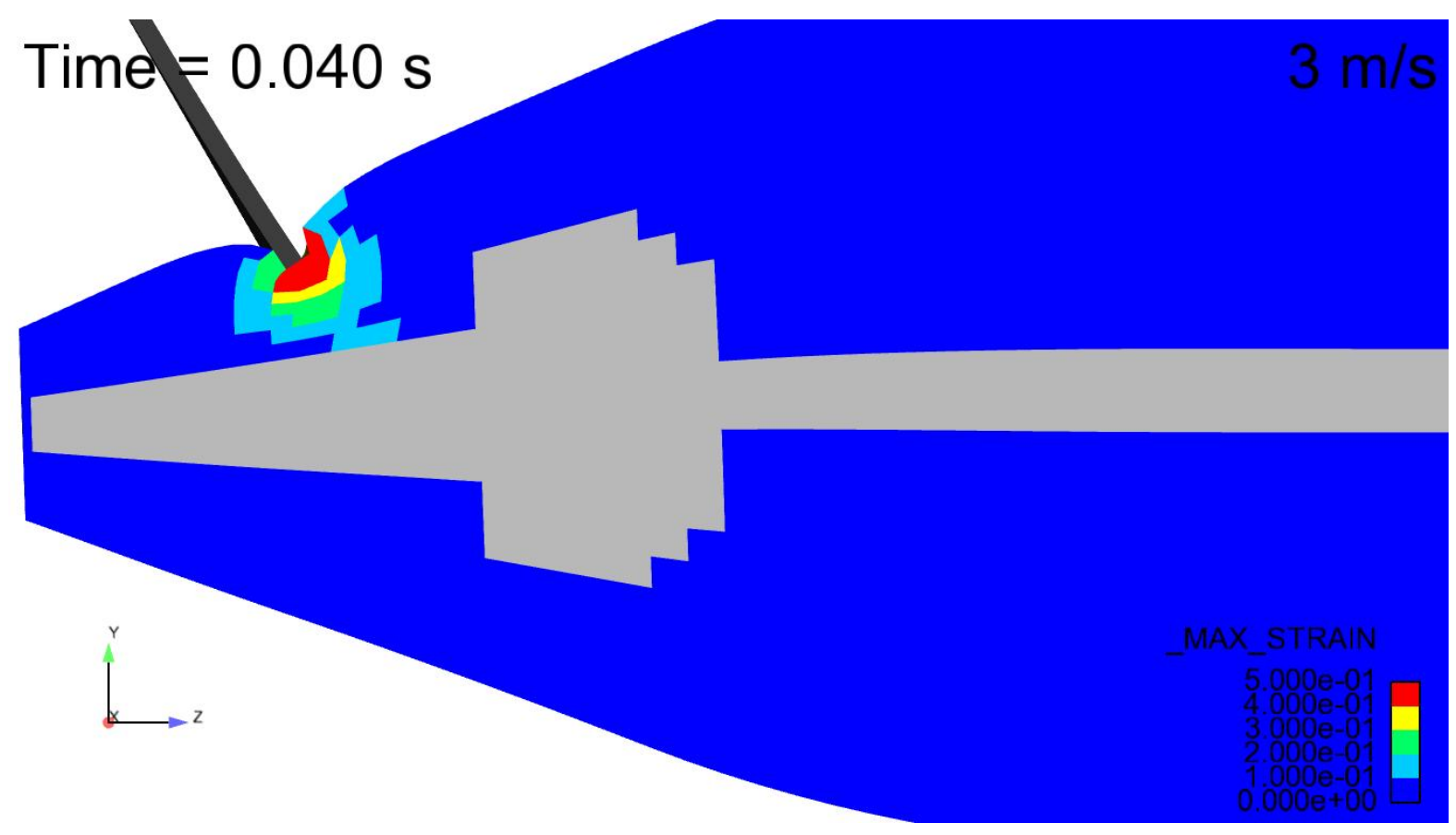

Figure 16. Strain, Standard Blade, $3 \mathrm{~m} / \mathrm{s}$ at Peak Load 


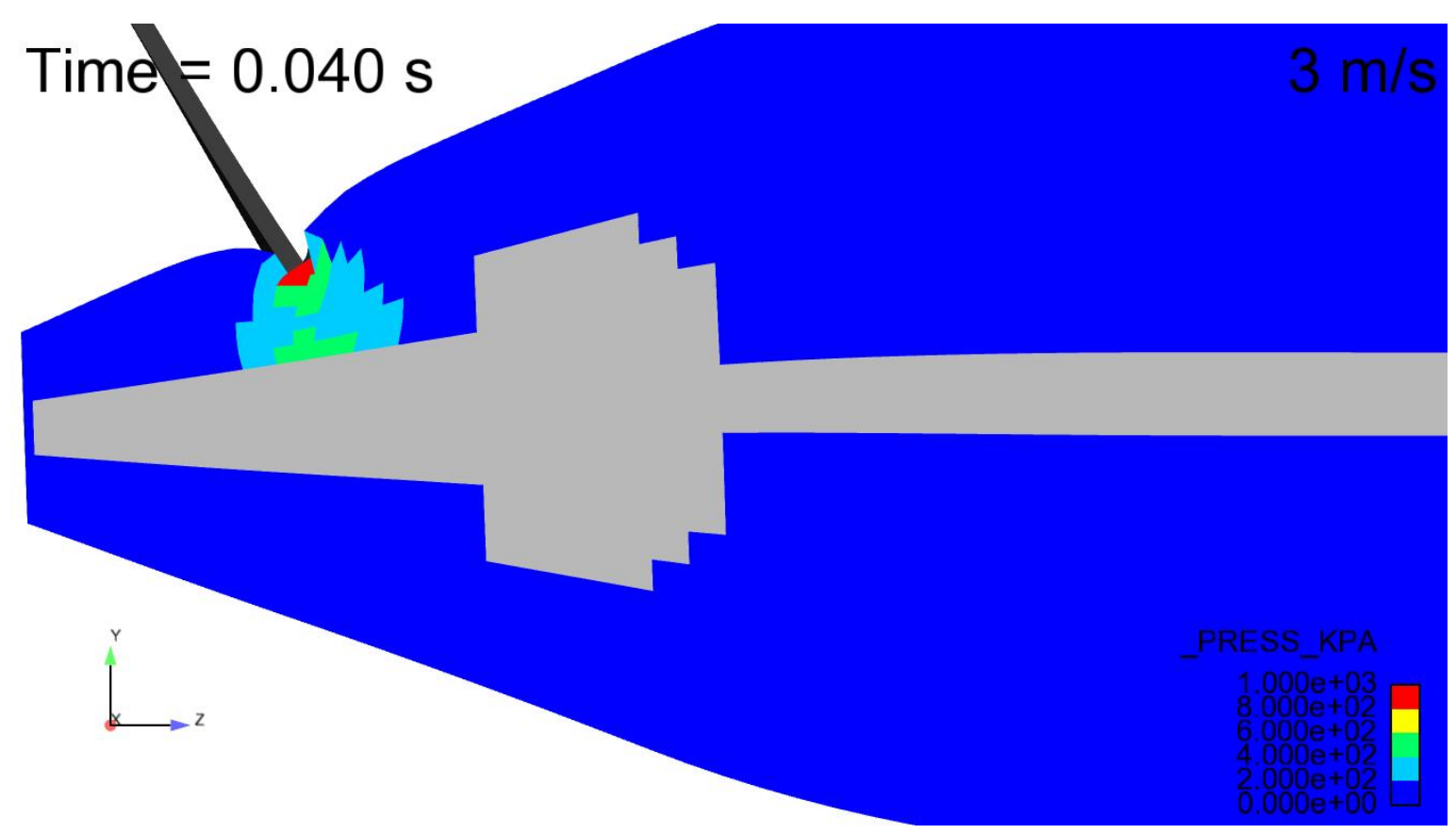

Figure 17. Pressure, Standard Blade, $3 \mathrm{~m} / \mathrm{s}$ at Peak Load

The model simulations could not be computed for impact velocities above $3 \mathrm{~m} / \mathrm{s}$ due the computational artifact of element distortion and inversion. However, one could extend the trend from 1 to $3 \mathrm{~m} / \mathrm{s}$ simulations to estimate strain and stress at the higher velocities. Figure 18 shows a plot of maximum strain and stress verses impact velocity. The relationship is linear within the velocity ranges of interest and is indicative of the linear material model used for the tissue. Because of the linear correlation, the following equations can be used to predict strain and stress for velocities between 1 and $5 \mathrm{~m} / \mathrm{s}$ :

$$
\begin{aligned}
& \text { Strain }=0.1+0.15 \mathrm{~V} \\
& \text { Stress }=250+700 \mathrm{~V}
\end{aligned}
$$




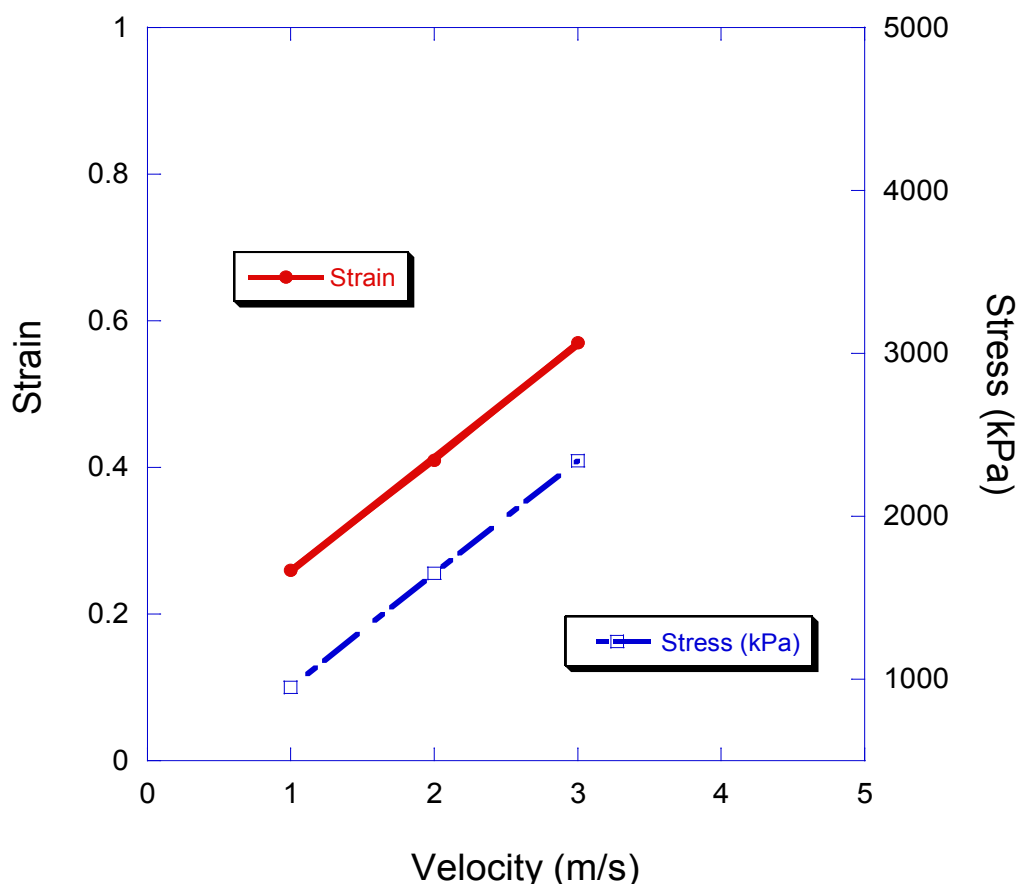

Figure 18. Maximum Strain (Log Strain) and Stress Verses Impact Velocity

Table 5 summarizes the peak strain and stress from equations 1 and 2 . These would be reasonable values for determining tissue effects due to impact.

Table 5. Peak Stress and Strain from Equations 1 and 2

\begin{tabular}{|c|c|c|c|}
\hline Blade Speed (m/s) & $\begin{array}{c}\text { Maximum Principal Log } \\
\text { Strain }\end{array}$ & $\begin{array}{c}\text { Maximum Elongation } \\
(\mathbf{\%})\end{array}$ & Maximum Pressure (kPa) \\
\hline 1 & 0.25 & 28 & 950 \\
\hline 2 & 0.40 & 49 & 1650 \\
\hline 3 & 0.55 & 73 & 2350 \\
\hline 4 & 0.70 & 101 & 3050 \\
\hline 5 & 0.85 & 134 & 3750 \\
\hline
\end{tabular}

\subsubsection{Including Forward Velocity of SRKW}

One could include the contribution of a forward swim velocity of the SRKW by using equations 1 and 2 and data from Table 1. Results from Noren, 2011 for swim speeds of killer whales under various scenarios suggest that a maximum speed of $3 \mathrm{~m} / \mathrm{s}$ is reasonable. This would create a net impact of $5.8 \mathrm{~m} / \mathrm{s}$ if the blade was moving at its maximum speed of $5 \mathrm{~m} / \mathrm{s}$. Using equations 1 and 2 , the resulting stress would be $4310 \mathrm{kPa}$ and the log strain would be 0.97 or 163 percent.

\subsubsection{Analysis Summary}

Some preliminary finite element analyses were performed to estimate the loading an adult male SRKW would experience if struck by a moving blade of a particular MHK device. Force-time histories are provided for several cases. Strain and pressure values in the whale tissue are also reported. 
Simulations with the standard blade did not run to completion for impact speeds greater than $3 \mathrm{~m} / \mathrm{s}$ because large shear deformations caused the element nearest the impact in the domain to distort and invert. Compared to commonly studied materials (metals, plastics, and composites), whale blubber and tissue are quite elastic and capable of very large deformations and strain without experiencing damage. The large strain in the models studied for impact velocities greater than $3 \mathrm{~m} / \mathrm{s}$ caused a localized element distortion in the domain and is simply an artifact of the element size and shape within the model. It should be noted that this artifact is due to the model treatment of the element size and shape within the domain and is not indicative of tissue damage.

\subsection{Conclusions of Engineering Analysis}

Although model simulations lacked convergence above $3 \mathrm{~m} / \mathrm{s}$, the results for 1 to $3 \mathrm{~m} / \mathrm{s}$ cover most of the range of turbine operation. In addition, the relationship between impact speed and stress or strain was linear between 1 and $3 \mathrm{~m} / \mathrm{s}$ allowing for reasonable extrapolation of results to higher velocity impact values of interest. The maximum stresses and strains calculated were $3750 \mathrm{kPa}$ and 134 percent respectively for the turbine impacting a stationary body. Including the forward velocity of the SRKW increased the stress and strain by 15 top 20 percent. The results demonstrated all stress values are well below the yield stress for similar materials like natural rubber which have values between 10,000 and $30,000 \mathrm{kPa}$ and the strain values are also well below the yield for similar materials like human skin/tissue and rubber which are on the order of 300-500 percent. More details on the interpretation of the results and comparison to the tissue effects for an SRKW are reported in the next section.

For future work, it is certainly possible to refine the analyses discussed in this report to provide more comprehensive and accurate results. Improvement s could be 1) better material representation of the various types of tissue could be incorporated, 2) further study of the element discretization could be done and, 3) more complicated material models such as Mooney-Rivlin could also be used if further data is available or generated. While the above improvements would allow for more accurate results, the approach for the scenarios and analyses reported here should be considered conservative for the study. 


\subsection{Biological Assessment of Consequences of Impact}

\subsection{Introduction}

Deployment of tidal turbines in Admiralty Inlet in Puget Sound is being considered with a concern surrounding the potential for interaction between the turbines and southern resident killer whales. Although the likelihood of encounter appears to be small, an assessment of the dynamics of strike by a turbine blade of an adult killer whale and the biological consequences of the strike has been conducted. This is the second part of the assessment, the first being an engineering analysis to estimate the force exerted on whale tissue by impact of a turbine blade striking the head of a killer whale.

We consider the elements of the exposure and finite element models used to generate estimates of the maximum pressure (stress) that an adult killer whale would experience as a function of turbine blade speed. The morphology of the head of a killer whale, as documented in CT scan data for a whale similar in size to that used in the engineering assessment, is used to consider assumptions about the exposure of an adult whale to turbine blade strike. We also review the model elements that affect assessment of the likely biological effects of blade strike, of which the most significant are the biomechanical properties of whale tissues. Of particular importance for the response of a whale to turbine blade strike are the properties of the skin and underlying fibroelastic connective tissues that form a protective barrier encasing a whale's body. Finally we consider the likely response of whale tissues given the estimated maximum pressure that the whale would experience during a blade strike as a function of the operational state of the tidal turbine.

\subsection{Whale Head Morphology}

The engineering analysis of impact modeled an adult killer whale that was approximately $650 \mathrm{~cm}$ in length, not considering the whale's flukes, and weighed 4,000 kg. We were able to locate CT scan data for the head of an adult female that weighed approximately 5,300 $\mathrm{kg}$ and was approximately $670 \mathrm{~cm}$ in length, including the flukes. Because of the similarity in size to the modeled case, the CT scan data is taken as a reasonable example of the size and location of features in the head of a killer whale of the size modeled in the engineering analysis of impact. The CT scan data presented in this report, which has not been published, was made available by Ted Cranford of Quantitative Morphology Consulting, Inc. and is reproduced here with his permission.

Figure 19 is a sagittal slice through the head of the whale. In Figure 19 bone is white, voids (air) are black, teeth are red, and soft tissues are other colors. Portions of the upper mandible of the whale's jaw and a cross section through the whale's skull are clear. The location of the transverse slice shown in Figure 20 is located approximately $40 \mathrm{~cm}$ from the anterior tip of the whale's head. The intersection of the transverse slice line and the upper surface of the whale's head is the approximate location used in the engineering analysis of impact as the location of impact of the turbine blade on the upper surface of the whale's head.

Figure 20 is the CT scan for a transverse slice through the head of the whale as indicated in Figure 19. In this figure bone is white, voids are black, and other tissues are gray. This slice intersects the lower mandibles of the whale's jaw, which are the "hook" shaped images to the right and left of center. The 
hollow voids in the whale's lower mandibles are filled with acoustic fat and other soft tissue and are believed to have a function in the reception of sound by the whale.

The whale's head is approximately $912 \mathrm{~mm}$ thick along the transverse slice line shown in Figure 19. In Figure 19 it appears that the mouth of the whale may have been somewhat agape when head was scanned. However, even considering this condition it is clear from Figure 19 and Figure 20 that the outline of the whale's head is oblong in shape, being compressed laterally. These images and data were not available when the finite element model of the whale's head used in the engineering analysis was constructed or when assessment of the extent of exposure of the whale's head to the turbine's blades was made. Given the turbine blade spacing of $550 \mathrm{~mm}$ shown in Figure 1, assuming that the approach of the whale would be straight toward the blade assembly, it seems that whales the size of this adult female would most likely not be able to extend their head into the blade assembly (blade length on the order of $1,250 \mathrm{~mm}$ ) to the extent used in the model, even more so if the turbine's shroud were considered in the analysis. Modeling the location of blade strike further posterior on the whale's head makes the assessment of the force of the strike absorbed by tissue conservative because the amount of blade strike energy that would have gone into "pushing" the whale away from the blade is increased as the location of strike is moved away from the center of mass of the whale.

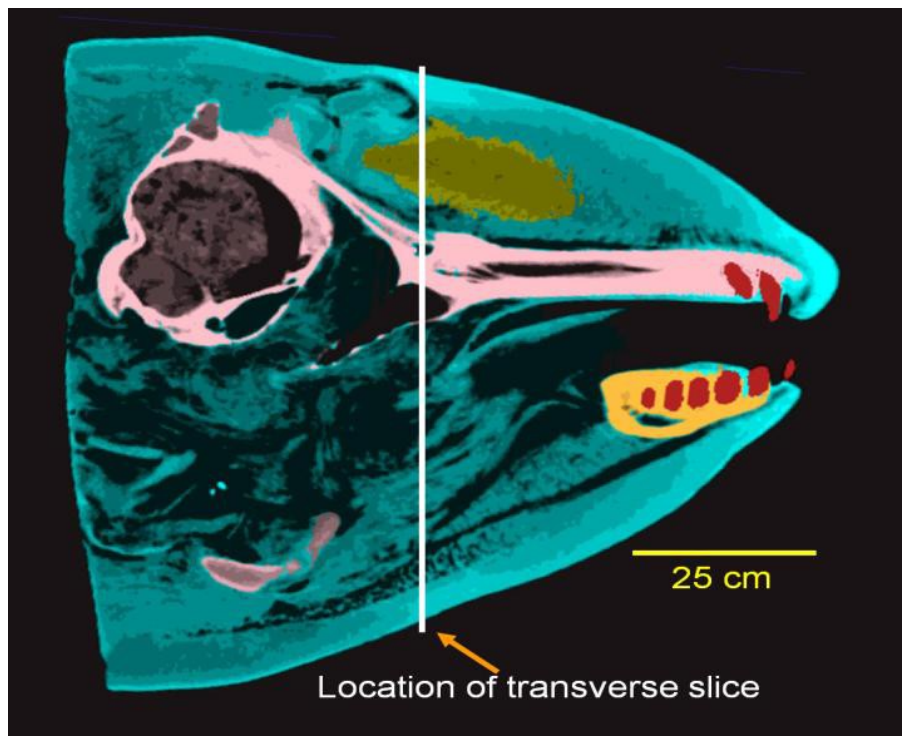

Figure 19. A Sagittal CT Scan of the Head of an Adult Killer Whale. In this scan bone is shown as white, teeth as red, voids are black, and other tissues in various other colors. 


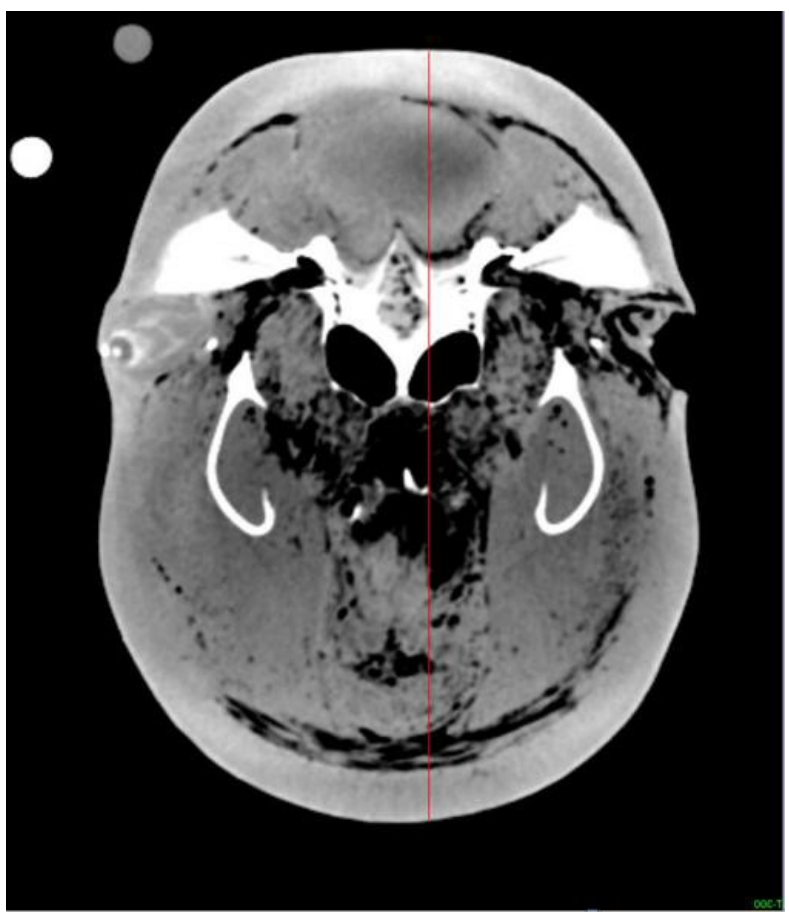

Figure 20. CT Scan of a Transverse Slice Through the Head of a Killer Whale Approximately $40 \mathrm{~cm}$ from the Tip of the Whale's Snout. The red line identifies a transect through the slice where CT scan image intensity values were sampled.

Figure 21 shows the CT scan image intensity data along a vertical transect through the transverse CT scan slice shown in Figure 20. CT scan image intensity data is proportional to the density of the tissue and bone. In Figure 21 the first data points are for higher density skin and fibroelastic connective tissues followed by lower density adipose and other tissue. Bone has the highest image pixel intensity. The $\mathrm{x}$-axis is incremented in index units that correspond to a physical length through the head of the whale of approximately $2.5 \mathrm{~mm}$ each. These data can be used to estimate the thickness of various tissues and the location of bone relative to the surface of the whale's head. Along this transect the high density tissue of the whale's skin and fibroelastic tissue are approximately $50 \mathrm{~mm}$ thick and the lower density adipose and connective tissue between this layer and the upper mandible bone is on the order of $200 \mathrm{~mm}$ thick. In total there is approximately $250 \mathrm{~mm}$ (9.8 in) of tissue with varying density and biomechanical properties between the upper surface of the whale's head and upper mandible bone along the transect shown in Figure 20. The tissues overlying the mandible in whales probably act as a "bumper" that absorbs and redistributes stresses applied to the surface of the whale (Campbell-Malone 2007). 


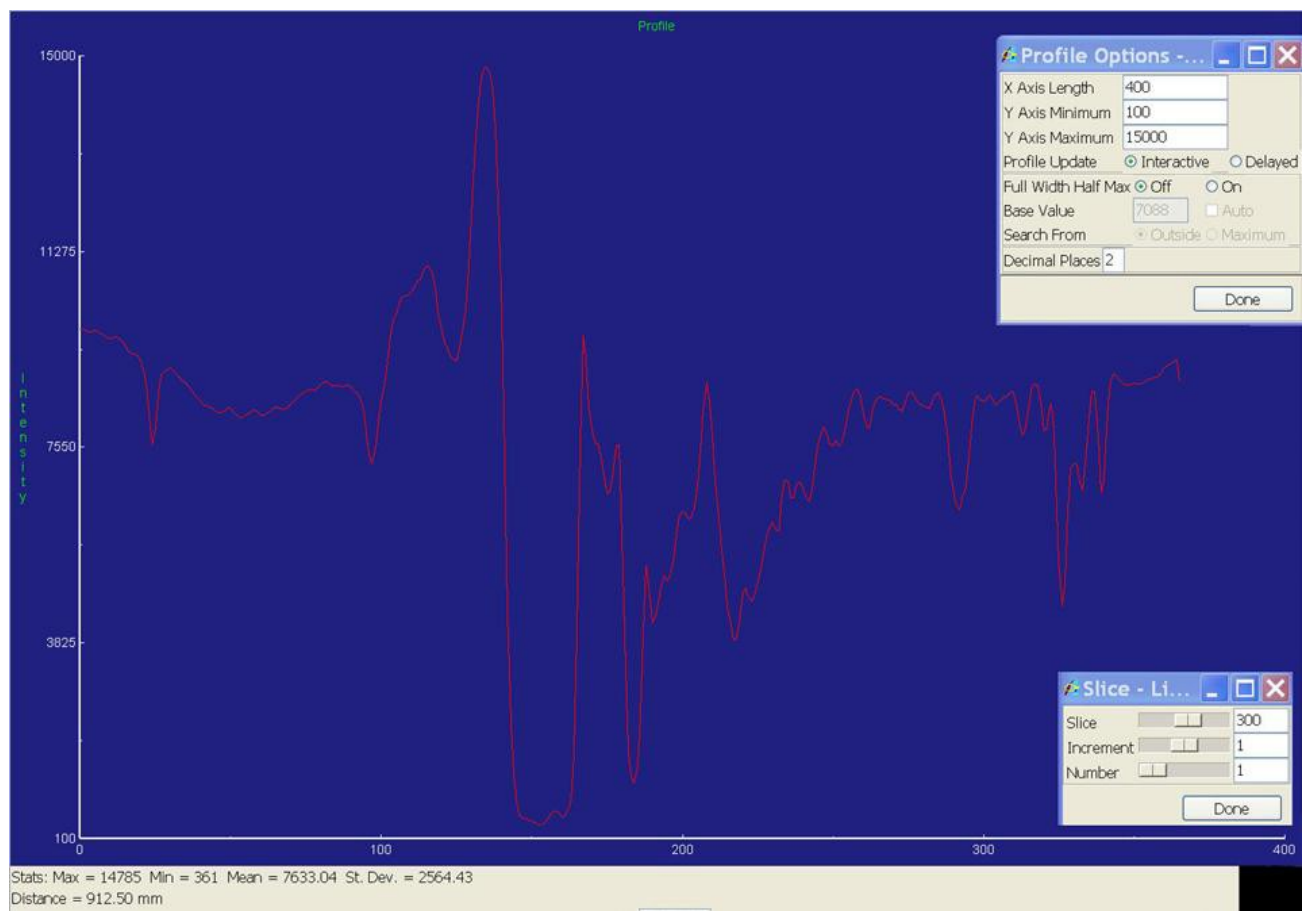

Figure 21. Intensity Values Along a Vertical Transect Through a Transverse Slice of CT Scan Data for the Head of a Killer Whale

In the engineering analysis the tissue of whale's head at and below the location of blade strike were modeled using the biomechanical properties of a single tissue, blubber. The CT scan data make it clear that this is not the case. This was known to be the case at the time the finite element model was constructed and the decision was made to model the whale's body using a single soft tissue. This decision was made because of the lack of biomechanical data for killer whale skin and higher density fibroelastic tissues. Because the higher density layers of tissue were not considered in the model, the resulting estimates of maximum pressure are conservative. The result of adding the high density skin and fibroelastic layer would most likely have been a distribution of the force of blade strike over a larger tissue area, which would have resulted in lower maximum pressures, probably significantly so.

\subsection{Tissue Models and Biomechanical Data}

Review of the published and gray literature, augmented by contact with known marine mammal researchers, determined that there was limited data for the biomechanical properties of whale tissue in general and for killer whales in particular. The majority of biomechanical data available has been taken primarily to investigate the production and reception of sound by those species that use echolocation to communicate and find food. Because of this, the available information is limited to the elastic region of tissue and bone stress-strain relationships with no examples where the responses of tissues were taken beyond this range to assess other properties such as the stress at which a tissue type mechanically failed. The soft tissue type with the most data available over the greatest range of stress was blubber (Soldevilla et.al. 2005). There was also information for whale bones (Campbell-Malone, 2007). Lacking was biomechanical data for whale skin and higher density fibroelastic tissue. Explanation of how available soft tissue and bone biomechanical information was abstracted from identified sources and used in the engineering assessment is contained in that report. 
Because of the known importance of the skin layer in mitigating impacts to the surface of any animal including whales, an effort was made to examine available information and to identify a material with known properties that might be used in strike response analysis as a surrogate for whale skin. We performed a literature review to determine if mechanical properties could be identified for killer whale skin.

The modulus of toughness is an important stress-strain feature of a material, such as whale skin, that is characterized by its ability to absorb energy. It is equal to the area under the stress-strain curve from the origin through the ultimate yield or rupture point for the material. As the term implies, toughness refers to the ability of a material to absorb energy without breaking. Unlike the modulus of elasticity, which is the constant of proportionality between stress and strain for elastic materials that response linearly to stress, the "modulus of toughness," UT, is a characteristic associated with susceptibility to puncture and laceration damage from mechanical trauma. The modulus of toughness is defined as the measure of a material's ability to plastically deform without fracturing. This is represented graphically in Figure 22. It is related to impact strength through the following equation:

$$
\mathrm{U}_{\mathrm{t}}=1 / 3\left(\varepsilon_{\mathrm{Br}}\right)\left(\sigma_{\mathrm{yp}}+2 \sigma_{\mathrm{ult}}\right)
$$

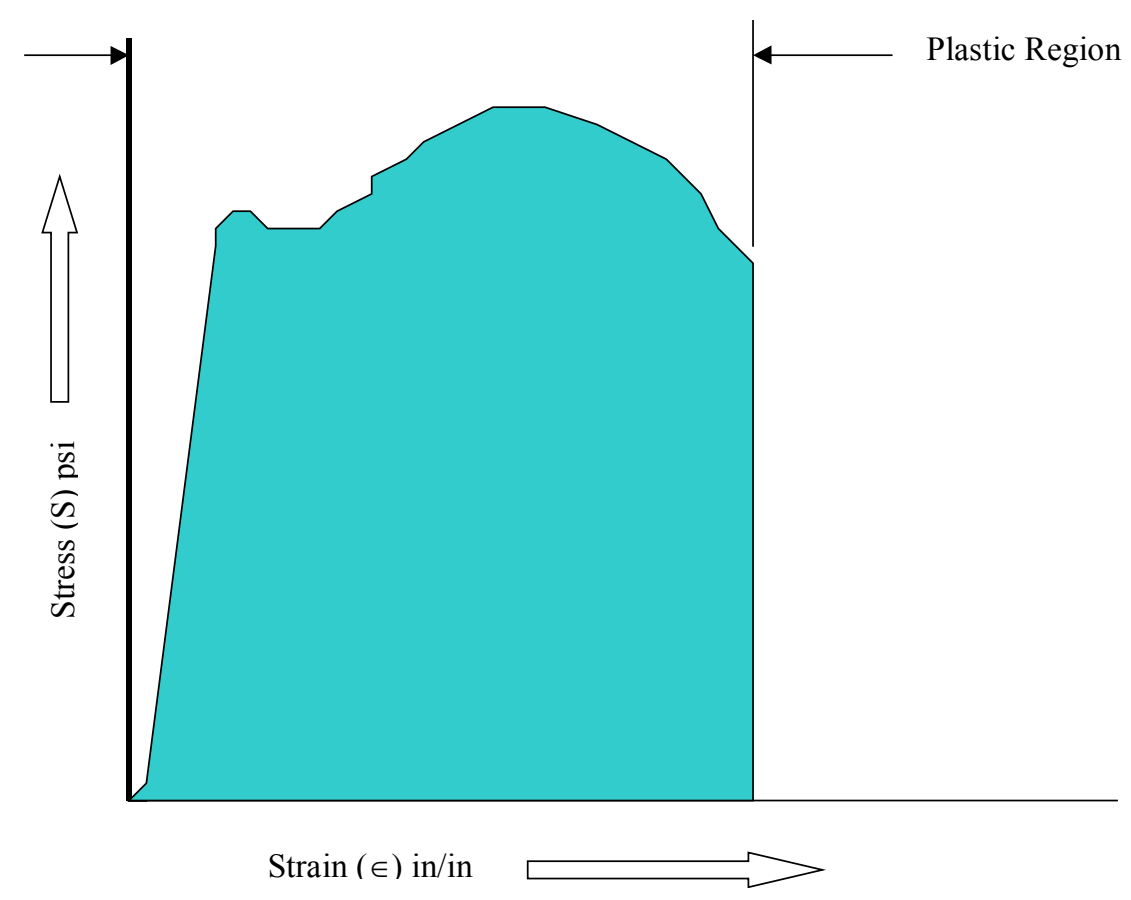

Figure 22. Description of Material Toughness in the Context of Stress-Strain Dynamics

The literature review determined that very little information exists for mechanical properties of whale skin. J.P. Winn (2006) in a master thesis that investigated the physical response of whale tissue to entanglement reported that:

"The dermal layer is composed of an extensively cross-linked network of collagen fibers that may function as an elastic recoil mechanism during swimming activities. However, to date the only structural studies on cetacean epidermis have been measurements of epidermal thickness and evaluations of surface properties, including surface roughness and resistance to biofouling. Epidermal thickness ... ranging from 
a minimum of $1.4 \mathrm{~mm}$ to a maximum of $25 \mathrm{~mm}$ in fin (Balaenoptera physalus) and bowhead whales (Balaena mysticetus) respectively. There have been no published studies on the mechanical properties of the cetacean epidermis."

Table 6. Comparative Epidermal Ranges Reported for Baleen Whale Species (Winn 2006)

\begin{tabular}{|c|c|c|c|c|c|c|}
\hline \multicolumn{7}{|c|}{ Epidermis Thickness: } \\
\hline 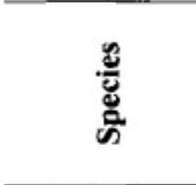 & 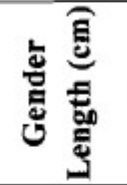 & 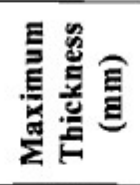 & $\frac{\mathscr{Z}}{\not{Z}}$ & 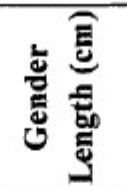 & 吾总 & 岕 \\
\hline $\begin{array}{l}\text { Balaena } \\
\text { mysticetus }\end{array}$ & $-\quad-$ & 25.0 & Haldiman et al. 1985 & $-\quad-$ & 8.6 & Haldiman et al. 1985 \\
\hline $\begin{array}{l}\text { Balaenoptera } \\
\text { acutorostrata }\end{array}$ & $-\quad-$ & 3.0 & Singarajah 1984 & - & 3.0 & Singarajah 1984 \\
\hline $\begin{array}{l}\text { Balaenoptera } \\
\text { acutorostrata }\end{array}$ & F 708 & 3.0 & Sokolov 1982 & F 708 & 1.4 & Sokolov 1982 \\
\hline $\begin{array}{l}\text { Balaenoptera } \\
\text { physalus }\end{array}$ & $\begin{array}{c}M 156 \\
5\end{array}$ & 3.9 & Sokolov 1982 & $\begin{array}{c}\text { F } 160 \\
0\end{array}$ & 2.5 & Giacometti 1967 \\
\hline $\begin{array}{l}\text { Eubalaena } \\
\text { glacialis }\end{array}$ & $\begin{array}{r}\text { M } 107 \\
5\end{array}$ & 13.2 & Sokolov 1982 & $\begin{array}{c}\text { F } 163 \\
0\end{array}$ & 8.6 & Sokolov 1982 \\
\hline $\begin{array}{l}\text { Megaptera } \\
\text { novaeangliae }\end{array}$ & M 857 & 5.6 & $\begin{array}{l}\text { Jones and Pfeiffer } \\
1994\end{array}$ & M 857 & 4.3 & $\begin{array}{l}\text { Jones and Pfeiffer } \\
1994\end{array}$ \\
\hline
\end{tabular}

TABLE 1. Comparative epidermal thickness ranges reported for baleen whale species.

Winn's thesis contains results from on abrasion tests on whale epidermis using 6.4-mm and 9.5-mm float line. Tests used straight pull and oscillatory pull under load to evaluate the effects of movement of rope across whale skin. The intent of the experiments was to model injury to the skin of whales struggling to free themselves from entanglement.

"Observations from both bowhead and right whales indicate that the primary strength in the epidermis is oriented in a vertical direction while laterally the structure is more elastic with lower strength. From a structural standpoint, this type of fiber integration would have several mechanical advantages. Strong vertically oriented fibers would both increase the abrasion resistance of the epidermis and may help to decrease the compressibility of the layer (Figure 23). As a lateral abrading force is applied to the surface of the epidermis, the strong vertical fibers would start to bend, orienting in the direction of the applied load. This flexure would allow the load to be applied in line with the vertical fibers that are anchored through the entire epidermal layer. Retaining elastic elements between these vertical fibers would maintain the flexibility needed in the epidermis allowing the epidermis to stretch during normal swimming activities. This elasticity may be graded through the stratum intermedium as the degree of keratinization and flattening of the epidermal cells has been noted to increase with distance from the sratum germinativum."

Winn also reports that "The depth of penetration and character of the dermal papillae may also substantially influence the strength of the epidermis as a unit. Assuming that a more multidirectional orientation of collagen fibers in the dermal material enhances the tensile properties of the dermis, the 
volume of this dermal material interwoven within the epidermis would substantially influence the structural characteristics of the layer."
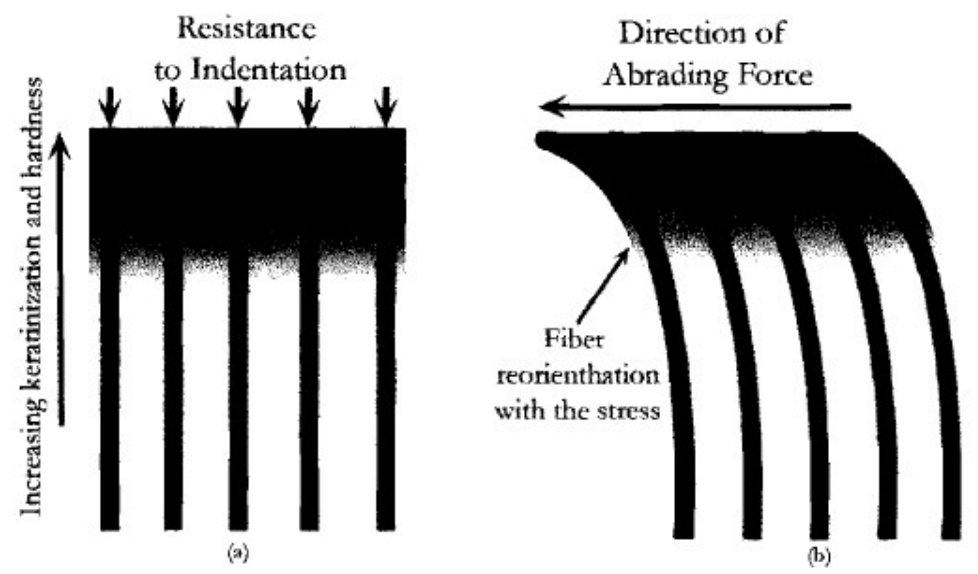

FIGURE 11. Structural advantages of a vertical fiber orientation within the epidermis. Fibers provide resistance to: (a) indentation and (b) lateral abrasion.

Figure 23. Structure of Whale Epidermis (Winn 2006)

Based on the information in Winn (2006), in the absence of biomechanical data for whale skin, it is recommended that a hyperelastic material (http://en.wikipedia.org/wiki/Hyperelastic_material) be used to model this layer. Figure 24and Table 7 below show properties of rubber and various elastomers.

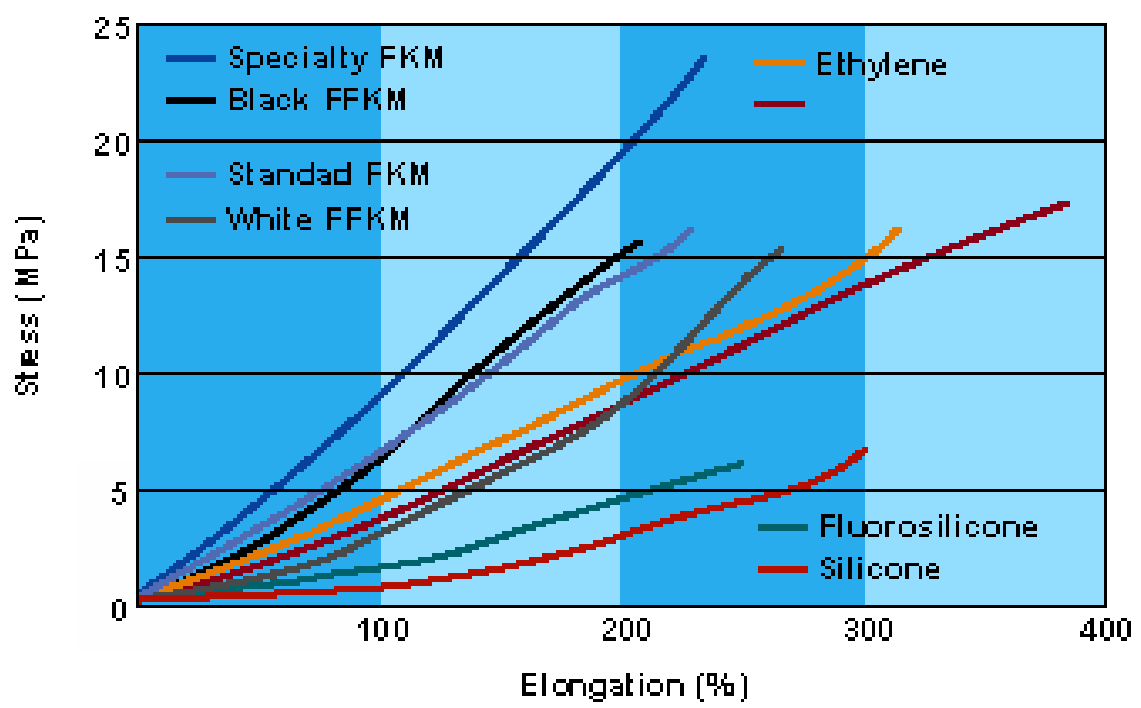

Figure 24. Examples Stress-Strain Characteristics for Some Manmade Elastomers (The Physics of Rubber, http://www.allsealsinc.com/allseals/Orings/or13.htm) 
Table 7. Properties of Various Elastomers (Schaefer 2009)

TABLE 33.2 Relative Properties of Various Elastomers

\begin{tabular}{|c|c|c|c|c|c|c|c|c|c|c|c|c|c|c|c|c|c|}
\hline ASTM designation & NR & BR & SBR & $\begin{array}{c}\text { IIR } \\
\text { CIIR }\end{array}$ & $\begin{array}{c}\text { EPM } \\
\text { EPDM }\end{array}$ & CSM & CR & NBR & HNBR & $\begin{array}{l}\text { ACM } \\
\text { ANM }\end{array}$ & $\mathrm{T}$ & FKM & FVMQ & $\begin{array}{l}\text { VMQ } \\
\text { MQ, } \\
\text { PMQ, } \\
\text { PVMQ }\end{array}$ & $\begin{array}{l}\mathrm{AU} \\
\mathrm{EU}\end{array}$ & GPO & $\begin{array}{c}\mathrm{CO} \\
\mathrm{ECO}\end{array}$ \\
\hline Durometer range & $30-90$ & $40-90$ & $40-80$ & $40-90$ & $40-90$ & $45-100$ & $30-95$ & $40-95$ & $35-95$ & $40-90$ & $40-85$ & $60-90$ & $40-80$ & $30-90$ & $35-100$ & $40-90$ & $40-90$ \\
\hline Tensile max, psi & 4500 & 3000 & 3500 & 3000 & 2500 & 4000 & 4000 & 4000 & 4500 & 2500 & 1500 & 3000 & 1500 & 1500 & 5000 & 3000 & 2500 \\
\hline Elongation max., \% & 650 & 650 & 600 & 850 & 600 & 500 & 600 & 650 & 650 & 450 & 450 & 300 & 400 & 900 & 750 & 600 & 350 \\
\hline Compression set & A & B & B & B & B-A & C-B & B & B & B-A & B & $\mathrm{D}$ & B-A & C-B & B-A & $\mathrm{D}$ & B-A & B-A \\
\hline Creep & A & B & B & B & C-B & $\mathrm{C}$ & B & B & B & C & D & B & B & C.A & C.A & B & B \\
\hline Resilience & High & High & Med. & Low & Med. & Low & High & Med-Low & Med. & Med. & Low & Low & Low & High-Low & High-Low & High & Med.-Low \\
\hline Abrasion resistance & A & $\mathrm{A}$ & A & C & B & A & A & A & A & C-B & $\mathrm{D}$ & B & $\mathrm{D}$ & B & A & $\mathrm{B}$ & C-B \\
\hline Tear resistance & A & B & $\mathrm{C}$ & B & C & B & B & B & B & D-C & D & B & D & C-B & A & A & C-A \\
\hline Heat aging at $212^{\circ} \mathrm{F}$ & C-B & C & B & A & B-A & B-A & B & B & A & A & C-B & A & A & A & B & B-A & B-A \\
\hline$T_{\mathrm{g}},{ }^{\circ} \mathrm{C}$ & -73 & -102 & -62 & -73 & -65 & -17 & -43 & -26 & -32 & $-24,-54$ & -59 & -23 & -69 & $-127,-86$ & $-23,-34$ & -67 & $-25,-46$ \\
\hline Weather resistance & D-B & D & D & A & A & A & B & $\mathrm{D}$ & A & A & B & A & A & A & A & A & B \\
\hline Oxidation resistance & B & B & $\mathrm{C}$ & A & A & A & A & B & A & A & B & A & A & A & B & B & B \\
\hline Ozone resistance & NR-C & NR & NR & A & A & A & A & $\mathrm{C}$ & A & B & A & A & A & A & A & A & A \\
\hline \multicolumn{18}{|l|}{ Solvent resistance } \\
\hline Water & A & A & B-A & A & A & B & B & B-A & A & D & B & A & A & A & C-B & C-B & B \\
\hline Ketones & B & B & B & A & B-A & B & $\mathrm{C}$ & $\mathrm{D}$ & D & D & A & NR & D & B-C & D & C-D & C-D \\
\hline Kerosene & NR & NR & NR & NR & NR & B & B & A & A & A & A & A & A & D-C & B & A-C & A \\
\hline Benzol & NR & NR & NR & NR & NR & C-D & C-D & B & B & C-B & C-B & A & B-A & NR & C-B & NR & B-A \\
\hline Alcohols & B-A & B & B & B-A & B-A & A & A & C-B & C-B & $\mathrm{D}$ & B & C-A & C-B & C-B & B & C & A \\
\hline Water glycol & B-A & B-A & B & B-A & A & B & B & B & A & C-B & A & A & A & A & C-B & B & C \\
\hline Lubricating oils & NR & NR & NR & NR & NR & A-B & B-C & A & A & A & A & A & A & B-C & A-B & D & A \\
\hline
\end{tabular}

$\mathrm{A}=$ excellent, $\mathrm{B}=$ good, $\mathrm{C}=$ fair, $\mathrm{D}=$ use with caution, $\mathrm{NR}=$ not recommended

SOURCE: Seals Eastern, Inc.

Table 8 shows mechanical properties from Matbase and Matweb for a wide variety of elastomers. In order to understand the effects of the whale skin layer on the results of turbine blade impact, it is recommended that multiple models be ran with hyperelastic materials such as natural rubber and fluorosilicone rubber that have properties that bound those of the materials in this category. 
Table 8. Table of the Mechanical Properties of Various Elastomers (http://www.matbase.com and http://www.matweb.com/ )

\begin{tabular}{|l|c|c|c|}
\hline \multicolumn{1}{|c|}{ Material } & $\begin{array}{c}\text { Ultimate Yield } \\
\text { Stress (kPa) }\end{array}$ & $\begin{array}{c}\text { Elongation/ Strain } \\
\mathbf{\%}\end{array}$ & $\begin{array}{c}\text { Young's Modulus } \\
\text { (MPa) }\end{array}$ \\
\hline Butadiene Rubber & 15000 & $200-400$ & \\
\hline Chloroprene Rubber (CR) & 25000 & $100-400$ & $2-15$ \\
\hline Chlorosulph PE & 20000 & $200-500$ & $2-10$ \\
\hline Ethenepropenediene Rubber & 20000 & $250-500$ & - \\
\hline Liquid Silicon Rubber & 7000 & $250-550$ & $2-5$ \\
\hline Natural Rubber (NR) & 30000 & $750-850$ & $1-5$ \\
\hline Nitrile Rubber (NBR) & 20000 & $200-500$ & $2-10$ \\
\hline Silicon Rubber (SI, Q, VMQ) & 8000 & $200-800$ & $2-10$ \\
\hline Styrenebutadiene Rubber (SBR) & 25000 & $250-700$ & - \\
\hline Urethane Rubber & 30000 & $300-400$ & - \\
\hline Butyl Rubber (IIR, CIIR, BIIR) & 17000 & $400-800$ & - \\
\hline Chlorosolfonated Polyethylene Rubber & 21000 & $200-500$ & - \\
\hline Epiclorohydrin Rubber (CO, ECO) & 17000 & $150-500$ & - \\
\hline Ethylene Propylene Rubber (EPM, EPDM) & 17000 & 600 & - \\
\hline Fluorosilicone Rubber (FMQ, FVMQ, FSI) & 8600 & $100-400$ & - \\
\hline Hydrogenated Nitrile Rubber (HNBR) & 30000 & $100-400$ & - \\
\hline Natural Rubber, Not Vulcanized (NR, IR, & 27600 & 500 & - \\
\hline Natural Rubber, Vulcanized (NR, IR, & 28000 & $100-800$ & - \\
\hline Polybutadiene Rubber (BR) & 17000 & $300-800$ & - \\
\hline Polychloroprene Rubber (CR) & 28000 & $100-800$ & - \\
\hline Polynorbornene Rubber (PNR) & 24000 & - & - \\
\hline Polyphosphazene Rubber (PZ, FZ) & 14000 & - & - \\
\hline Propylene Oxide Rubber (GPO) & 17000 & - & - \\
\hline
\end{tabular}

\subsection{Summary of Engineering Analysis}

The summary findings from the engineering analysis are presented in Table 5 of the report of that analysis. This table is copied below.

Table 9. Copy of Table 5 from the Sandia Report of the Results of Engineering Analysis of the Turbine Blade Strike. The table contains the estimated peak stress in terms of pressure and strain in terms of maximum elongation on whale tissue from strike by a turbine blade by blade speed.

\begin{tabular}{|c|c|c|c|}
\hline $\begin{array}{c}\text { Blade Speed } \\
(\mathbf{m} / \mathbf{s})\end{array}$ & $\begin{array}{c}\text { Maximum Principal Log } \\
\text { Strain }\end{array}$ & $\begin{array}{c}\text { Maximum Elongation } \\
\mathbf{( \% )}\end{array}$ & $\begin{array}{c}\text { Maximum Pressure } \\
\mathbf{( k P a )}\end{array}$ \\
\hline 1 & 0.25 & 28 & 950 \\
\hline 2 & 0.40 & 49 & 1650 \\
\hline 3 & 0.55 & 73 & 2350 \\
\hline 4 & 0.70 & 101 & 3050 \\
\hline 5 & 0.85 & 134 & 3750 \\
\hline
\end{tabular}




\subsection{Biomechanics of Human Skin}

Human skin has the same basic construction as whale skin with an epidermis, dermis, hypodermis and a fourth layer connecting the skin to underlying tissue. Human skin has been found be behave as a nonhomogenous, anisotropic, non-linear viscoelastic material (Hendriks 2001). A basic function of the skin is to protect the body from mechanical injury.

The stress-strain relationship for human skin is shown in Figure 25 (copied from Figure 2 in Silver et.al. 2001). The top line in Figure 25 is the true stress-strain curve for human skin; the two below are elastic and viscous stress-strain curves.

The relationship between stress and strain for human skin show trends that are similar to those predicted for whale blubber in the engineering analysis of the effect of blade strike (Table 5) considering blubber does not include the epidermis and dermis layers, which give skin many of its composite biomechanical properties. For example, the engineering analysis estimates that at a pressure of $2.35 \mathrm{MPa}$, which corresponds to a blade strike at a turbine speed of $3 \mathrm{~m} / \mathrm{s}$, blubber will show an elongation of about 73 percent. In Figure 25 it can be seen that this same level of stress experienced by human skin would result in an elongation (strain) of about 60 percent. At the highest turbine speed for which the response of blubber is considered in the engineer analysis, $5 \mathrm{~m} / \mathrm{s}$, an elongation of 134 percent was predicted at an pressure of $3.75 \mathrm{MPa}$. In Figure 25 it can be seen that for the skin as a whole this level of stress would only result in a small increase in elongation from that for a stress of $2.35 \mathrm{MPa}$. The difference, considering the data for human skin, is probably due to blubber being more viscous and less elastic than whole whale's skin. In fact, it is likely that whale skin, because of the differences in the dermal layer between humans and whales, would have a stress-strain curve that would have a steeper slope than that shown for human skin.

It seems highly likely that consideration of the epidermal and dermal layers of whale skin in addition to the hypodermis (blubber) would result in values for strain lower than those predicted for blubber alone, while remaining in the range of elastic response well away from stress levels that would damage the whale's skin. 


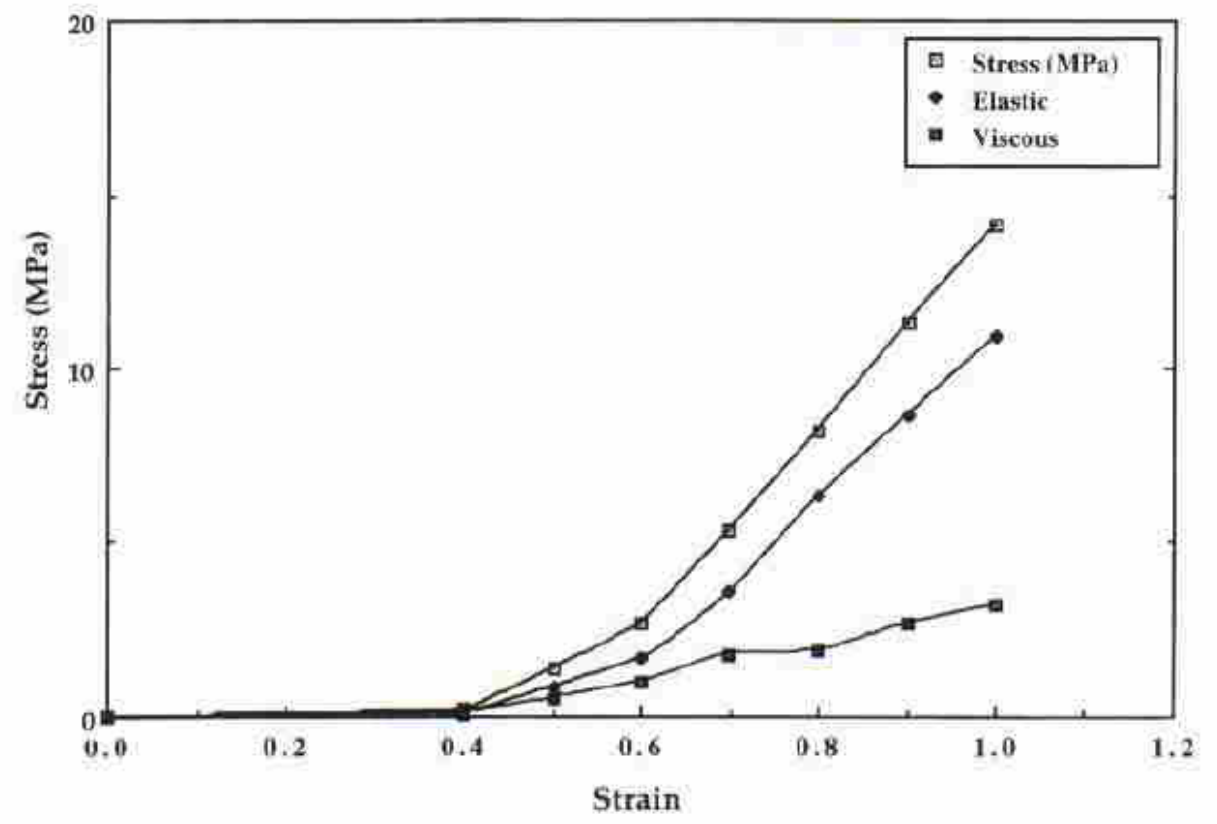

Figure 25 Relationship Between Stress and Strain for Human Skin Showing True Stress (unfilled squares), Elastic (diamond symbols), and Viscous (filled squares) Components (Silver et al., 2001)

\subsection{Consequence of Turbine Blade Impact on Whale Tissue}

The consequence of tidal turbine blade impact on whale tissue can be roughly estimated from the model data in Table 4 . The data in Table 4 are worst case for the soft tissue found below the skin and fibroelastic layers of whale tissue. The reason that they are worst case is that the likely properties of the skin and associated fibrous layer would have acted as a membrane and would have distributed the force of the blade strike over a larger area of underlying tissue.

If it can be assumed that whale skin can be modeled as a hyperelastic material, the stress-elongation curves in Figure 18 indicate that at the maximum pressure of $3.75 \mathrm{MPa}(3750 \mathrm{kPa})$ the response of whale skin would remain in the elastic range for all the materials presented. Elongation percentages at the highest turbine blade speed would be in the range from approximately 25 percent to 200 percent with that for materials in the middle of the range of about 100 percent. At all other blade speeds elongation would be less. Because the response of these materials is elastic over the range of pressures in Table 4, it is expected that if whale skin behaves similarly to these materials, at strike whale skin tissue would deform and, in conjunction with underlying soft tissue, absorb the force of the strike and would return to normal condition a short time after the pressure was removed. These data indicate that the skin would not fail, i.e. be torn by the impact at even the highest exposure pressures.

The analysis of the blubber mechanical property data conducted during model construction based on measured biomechanical properties of blubber suggests that blubber has properties that are similar to rubber like as well. As such the whale blubber would display elastic properties with elongation response to stress without deformation within the range of pressures predicted by the engineering analysis. It is possible that within this range of pressure and resulting deformation that the tissues experiencing the 
highest pressures would bruise. It is expected that the pressures listed in Table 4 would not be realized because the skin and underlying fibrous fatty tissue would deform to distribute the force of the strike across a greater area of tissue.

Campbell-Malone (2007) gives a value for the ultimate compressive strength for trabecular right whale mandible bone of $17.95 \mathrm{MPa}$. The ultimate strength for cortical bone would be higher. If this value can be used for killer whale mandibular bone, the highest pressure predicted (3.75 MPa) is well below the pressure at which this bone would be expected to fracture. Because the skin and other tissues overlaying the killer whale mandible would absorb most if not all of the pressure from the blade strike the pressure on the whale's mandible would likely be an order of magnitude or so below pressure likely to cause fracture.

\subsection{Further Questions}

The engineering and biological assessments conducted for this analysis of strike of a whale by a tidal turbine blade have shown that such analysis can provide insight to possible interactions between marine animals and turbines. It is clear that the information base for the mechanical properties of marine mammal tissues lacks key pieces of information critical to engineering and biological analysis of interaction between marine mammals and marine power production devices. In addition, a better developed data base of marine mammal biomaterial properties and animal models would assist with the evaluation or design of machines, such as material properties for the leading edges of turbine blade that would damage animals less if contact were made; however, in the absence of these data this analysis considered conservative estimations and therefore, the overall conclusions reached would be unlikely to significantly change with additional information.

We recommend a coordinated action to recover more biomechanical information about marine mammal tissues and bone as a routine part of the existing activity to necropsy marine mammals to determine cause of death when they are found ashore dead. 


\subsection{References}

Campbell-Malone R. 2007. Biomechanics of North Atlantic Right Whale Bone: Mandibular Fracture as a Fatal Endpoint for Blunt Vessel-Whale Collision Modeling, Massachusetts Institute of Technology, Woods Hole Oceanographic Institution, Woods Hole, Massachusetts.

Durban J, H Fearnbach, D Ellifrit, and K Balcomb. 2009. Size and Body Condition of Southern Resident Killer Whales. Contract report to the Northwest Regional Office, National Marine Fisheries Service. Order number AB133F08SE4742, Requisition Number NFFP5000-8-43300.

Hendriks, FM. 2001. Mechanical behavior of human skin in vivo, a literature review. Koninklijke Philips Electronics N.V. Amsterdam, the Netherlands, Report 2001/820.

Koteras J R, AS Gullerud, NK Crane, and JD Hales. 2006. Presto User's Guide Version 2.6. Sandia National Laboratories, Albuquerque, New Mexico, SAND2006-6093.

McKenna FA. 2005. Comparative Morphology of the Odontocete Melon: Functional and Evolutionary Interpretations. San Diego State University, San Diego, California.

Noren DP 2011. "Estimated field metabolic rates and prey requirements of resident killer whales. Marine Mammal Science, 27(1):60-77.

Schaefer RJ. 2009. "Mechanical Properties of Rubber." In Harris Shock and Vibration Handbook, eds. AG Piersal and TL Paez, McGraw Hill, New York, New York.

Sliver, FH, JW Freeman, and D DeVore. 2001. "Viscoelastic properties of human skin and precessed dermis." Skin Research and Technology, 18-23.

Soldevilla MS, MF McKenna, SM Wiggins, RE Shadwick, TW Cranford, and JA Hildebrand. 2005. "Cuvier's beaked whale (Ziphius cavirostris) head tissues: physical properties and CT imaging." Journal of Experimental Biology, 208:2319-2332.

Winn, JP. 2006. Modeling Large Whale Entanglement Injuries: An Experimental Analysis of the Influence of Tissue Compliance, Line Tension, and Draw-Length on Epidermal Abrasion Resistance, University of Maine, Orono, Maine. 


Prepared for the U.S. Department of Energy under Contract DE-AC05-76RL01830

\section{Pacific Northwest}

NATIONAL LABORATORY

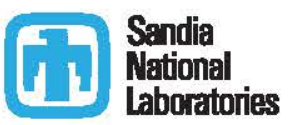

Proudly Operated by Battelle Since 1965

902 Battelle Boulevard

P.O. Box 999

Richland, WA 99352

1-888-375-PNNL (7665)

www.pnnl.gov 